University of Nebraska - Lincoln

DigitalCommons@University of Nebraska - Lincoln

\title{
The response of the Ligurian and Tyrrhenian Seas to a summer Mistral event: A coupled atmosphere-ocean approach
}

\author{
R.J. Small \\ National Center for Atmospheric Research, jsmall@ucar.edu \\ S. Carniel \\ Consiglio Nazionale delle Ricerche \\ T. Campbell \\ Stennis Space Center \\ J. Teixeira \\ NASA Jet Propulsion Laboratory \\ R. Allard \\ Stennis Space Center
}

Follow this and additional works at: https://digitalcommons.unl.edu/usnavyresearch

Small, R.J.; Carniel, S.; Campbell, T.; Teixeira, J.; and Allard, R., "The response of the Ligurian and Tyrrhenian Seas to a summer Mistral event: A coupled atmosphere-ocean approach" (2012). U.S. Navy Research. 46.

https://digitalcommons.unl.edu/usnavyresearch/46

This Article is brought to you for free and open access by the U.S. Department of Defense at DigitalCommons@University of Nebraska - Lincoln. It has been accepted for inclusion in U.S. Navy Research by an authorized administrator of DigitalCommons@University of Nebraska - Lincoln. 


\title{
The response of the Ligurian and Tyrrhenian Seas to a summer Mistral event: A coupled atmosphere-ocean approach
}

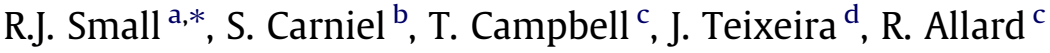 \\ ${ }^{a}$ National Center for Atmospheric Research, Climate and Global Dynamics Division, 1850 Table Mesa Drive, Boulder, CO 80305, USA \\ ${ }^{\mathrm{b}}$ Consiglio Nazionale delle Ricerche, ISMAR, Castello, 2737-F, 30122 Venice, Italy

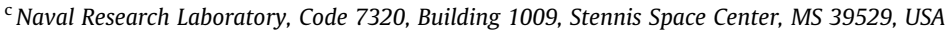 \\ ${ }^{\mathrm{d}}$ NASA Jet Propulsion Laboratory, M/S 169-237, 4800 Oak Grove Drive, Pasadena, CA 91109, USA
}

\section{A R T I C L E I N F O}

\section{Article history:}

Received 15 August 2011

Received in revised form 10 February 2012

Accepted 12 February 2012

Available online 22 February 2012

\section{Keywords:}

Air-sea interaction

Coupled modeling

Ocean heat budget

Ocean circulation

Ocean winds

Ocean temperature

\begin{abstract}
A B S T R A C T
In this paper the effect of a summer Mistral event on the Ligurian and Tyrrhenian Seas in the northwestern Mediterranean is discussed, using a coupled numerical model and satellite and in situ observations. The focus is on the spatial and temporal distribution of the ocean mixed layer response to the strong winds, and on how this is affected by atmosphere-ocean coupling. The model used is the Coupled Ocean-Atmosphere Mesoscale Prediction System $\left(\right.$ COAMPS $^{\circledR 1}$ ), developed at the Naval Research Laboratory. This system includes an atmospheric sigma coordinate, non-hydrostatic model, coupled to a hydrostatic sigma-z level ocean model (Naval Coastal Ocean Model), using the Earth System Modeling Framework (ESMF). The model is run at high (km scale) resolution to capture the fine structure of wind jets and surface cooling.

Two non-assimilating numerical experiments, coupled and uncoupled, are run for a 3-day period of a Mistral event, to examine more closely the impact of coupling on the surface flux and sea surface temperature (SST) fields. The cooling of SST up to $3^{\circ} \mathrm{C}$ over $72 \mathrm{~h}$ in the coupled run significantly reduced the surface momentum and heat fluxes, relative to the uncoupled simulation, where the SST was kept fixed at the initial value. Mixed layer depths increase by as much as $30 \mathrm{~m}$ during the event. A heat budget analysis for the ocean is carried out to further explain and investigate the SST evolution. Shear-induced mixing in inertial waves is found to be important to the surface cooling. Effects of coupling on the atmospheric boundary layer are found to be significant, but overall the effect of coupling on the synoptic low pressure system is small.
\end{abstract}

(c) 2012 Elsevier Ltd. All rights reserved.

\section{Introduction}

The north-west Mediterranean Sea is subject to frequently occurring wind events associated with cyclogenesis in the lee of the Alps (Buzzi and Speranza, 1983; Pettre, 1982). The typical situation has a low centered in the Gulf of Genoa, with synoptic northerly flow impinging on the mountain ranges, and being funneled by gaps in the topography. This leads to strong topographic jets: the northerly Mistral flowing between the Alps and Massif Central and down the Rhone valley: and the north-westerly Tramontane between the Massif Central and the Pyrenees.

Mistral and Tramontane events are associated with large airsea fluxes (Flamant, 2003) and a significant ocean response (Estournel et al., 2003). In winter the surface winds can have speeds greater than $20 \mathrm{~m} \mathrm{~s}^{-1}$, with air temperatures below $5^{\circ} \mathrm{C}$,

\footnotetext{
* Corresponding author. Tel.: +1 303497 1387; fax: +1 3034971700 .

E-mail address: jsmall@ucar.edu (R.J. Small).

${ }^{1}$ COAMPS $^{\circledR}$ is a registered trademark of Naval Research Laboratory.
}

and they blow over sea surface temperatures of about $13^{\circ} \mathrm{C}$. The resulting surface turbulent sensible and latent heat fluxes can combine to reach over $400 \mathrm{Wm}^{-2}$, cooling the ocean and leading to deep convection in the Gulf of Lions (Schott et al., 1996). Mistral and Tramontane events also occur in summer (Drobinski et al., 2005), with the low pressure systems typically occurring about 10 times (Millot, 1979), approximately half as many times as in winter (Buzzi and Speranza, 1983).

In early summer the increase in solar insolation and a reduction in the frequency of strong winds leads to a restratification of the upper ocean in the north-west Mediterranean Sea. For example, by the middle of June in the Gulf of Genoa, the surface temperature is around $22^{\circ} \mathrm{C}$, the mixed layer is just $10 \mathrm{~m}$ deep, and there can be a $6-8{ }^{\circ} \mathrm{C}$ difference between the surface temperature and the temperature near $50 \mathrm{~m}$ depth (see Fig. 1, and Allard et al., 2010).

The primary aim of this study is to examine the response of the Ligurian and Tyrrhenian Seas to a summer Mistral event using a coupled mesoscale ocean-atmosphere model. Because the mixed layer is quite shallow, there is a potential to significantly reduce 

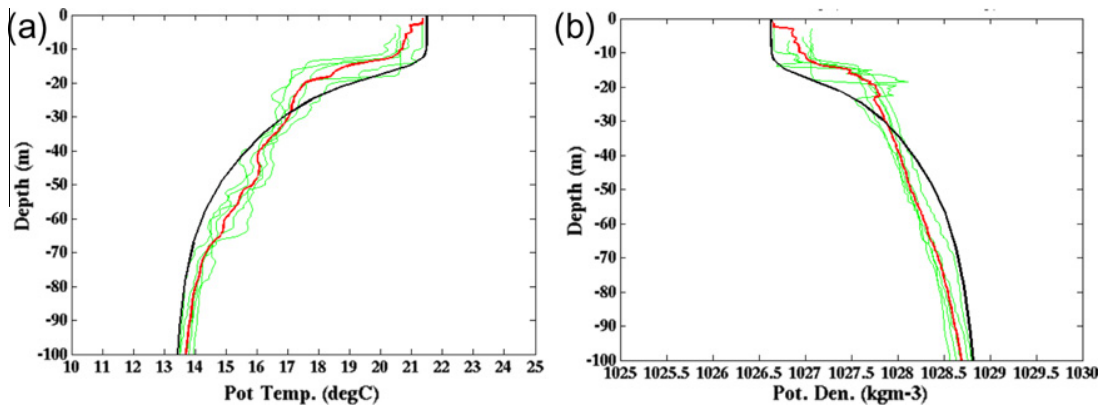

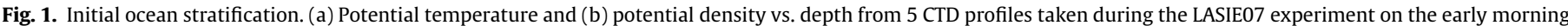

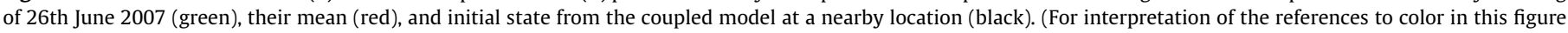
legend, the reader is referred to the web version of this article.)

the SST during strong winds in summer, through upwelling and entrainment of thermocline water into the mixed layer. In addition the wind jets can affect the ocean restratification process by potentially deepening the mixed layer. The SST response can provide feedback to the surface stress and heat flux forcing. We examine this effect by comparing the fully interactive ocean-atmosphere model with a simulation with feedback from ocean to atmosphere (via SST) switched off.

To the best of our knowledge the Mistral has not been analysed before in detail using a high resolution fully coupled model for a summer case. Although Mediterranean Sea ocean modeling has had a long history (see e.g. Malanotte-Rizoli and Robinson, 1994; Pinardi and Masetti, 2000; Pinardi et al., 2003; Barth et al., 2005), only recently have coupled models been used to study basin scale effects (Somot et al., 2008; Artale et al., 2010). In a related paper to this study, Lebaupin-Brossier and Drobinski (2009) investigated the air-sea interaction during winter Mistral events using the atmospheric Weather Research and Forecasting (WRF) model coupled to a mixed layer ocean model. In their case the maximum surface cooling observed was around $1^{\circ} \mathrm{C}$ in the Gulf of Lions in a November event. In our summertime event, the cooling is larger $\left(2-3^{\circ} \mathrm{C}\right)$ and interactive coupling has the potential to be more important.

This paper is a companion to Small et al. (2011) which performed and validated a month long simulation of the coupled model against in situ data from the Ligurian Sea Air-Sea Interaction Experiment (LASIE07, Sempreviva et al., 2010). The paper is structured as follows. Section 2 introduces the model, the satellite and in situ observations, and describes the model experiments. Section 3 summarizes the Mistral case study, focusing on the near surface winds, wind stress, and Ekman pumping. Section 4 describes the surface ocean response in terms of temperature and currents. Then Section 5 shows the distribution of air-sea fluxes and discusses the sensitivity of SST evolution to air-sea coupling. Section 6 examines the ocean sub-surface response, including a heat budget and description of inertial wave effects. Section 7 is a brief discussion of the atmospheric response to full coupling. This is followed by a Conclusions section.

\section{Models, observations and methods}

\subsection{COAMPS numerical model}

Numerical simulations are performed with the Coupled OceanAtmosphere Mesoscale Prediction System (COAMPS ${ }^{\circledR}$ ), developed at the Naval Research Laboratory. The atmospheric component is a terrain-following sigma coordinate, non-hydrostatic model (Hodur, 1997; Chen et al., 2003). The ocean component is the hydrostatic Navy Coastal Ocean Model (NCOM), which uses a combination of terrain following sigma and $z$-level coordinates (Martin, 2000; Martin et al., 2006). The model is based on the Princeton Ocean Model (Blumberg and Mellor, 1987) and also includes a free surface. The model domains and resolutions are identical to those used in (Small et al., 2011, see Fig. 3 of that paper). The atmosphere has three nests of horizontal spacing $36 \mathrm{~km}, 12 \mathrm{~km}$ and $4 \mathrm{~km}$ respectively, each nest having 40 vertical layers. The ocean model was set up with an outer and inner nest with $6 \mathrm{~km}$ and $2 \mathrm{~km}$ grid spacing respectively, with a total of 50 vertical levels in each. Full details of the COAMPS version used in this study, including technical details of the coupling and the physical schemes employed, can be found in Chen et al. (2010), Jensen et al. (2011), and Small et al. (2011).

\subsection{Satellite and in situ data}

Equivalent neutral wind vectors at $10 \mathrm{~m}$ (Wentz and Smith, 1999) are derived from the SeaWinds QuikSCAT scatterometer, and obtained from the Remote Sensing Systems web site (www.remss.com). The twice-daily (approximately 0600 and 1800 local time) data is mapped onto a regular Cartesian 1/4 degree grid.

We use an optimal interpolation of infrared satellite SST provided by the GOS group at Institute of Atmospheric Sciences and Climate, Consiglio Nazionale delle Richerche (CNR-ISAC) in Rome (Marullo et al., 2007). This product utilizes Advanced Very High Resolution Radiometer (AVHRR) and other infrared satellite data gathered during nighttime, when the expected differences with in situ bulk SST are expected to be at a minimum.

Near surface wind and ocean temperature data is obtained from the Ligurian Sea Air-Sea Interaction Experiment (LASIE07, Teixeira, 2007; Sempreviva et al., 2010; Carniel et al., 2010; Small et al., 2011), in particular from the Ocean Data Acquisition System $(O D A S)$, located at $9^{\circ} 9.8 \mathrm{E}, 43^{\circ} 47.36 \mathrm{~N}$, and from conductivity-temperature-depth (CTD) profiles gathered from the Research Vessel Planet.

\subsection{Model experiments}

A short pair of simulations was performed, covering the 3 day period of 26th June 2007 to the 28th June, a period of Mistral winds in the Ligurian Sea. The first simulation is a fully coupled run, referred to as Run C, in which atmospheric and oceanic fields are updated every $12 \mathrm{~min}$ for the surface flux calculations. The second simulation is uncoupled (Run $U$ ). In this uncoupled case, the surface fluxes are computed using the initial, unchanging SST ("persistence"). The reason for this uncoupled configuration is that it mimics a more traditional $72 \mathrm{~h}$ operational atmospheric forecast using a fixed SST field (e.g. using a single analysed SST field from the Navy Coupled Ocean Data Assimilation system (NCODA, Cummings, 2005)). 

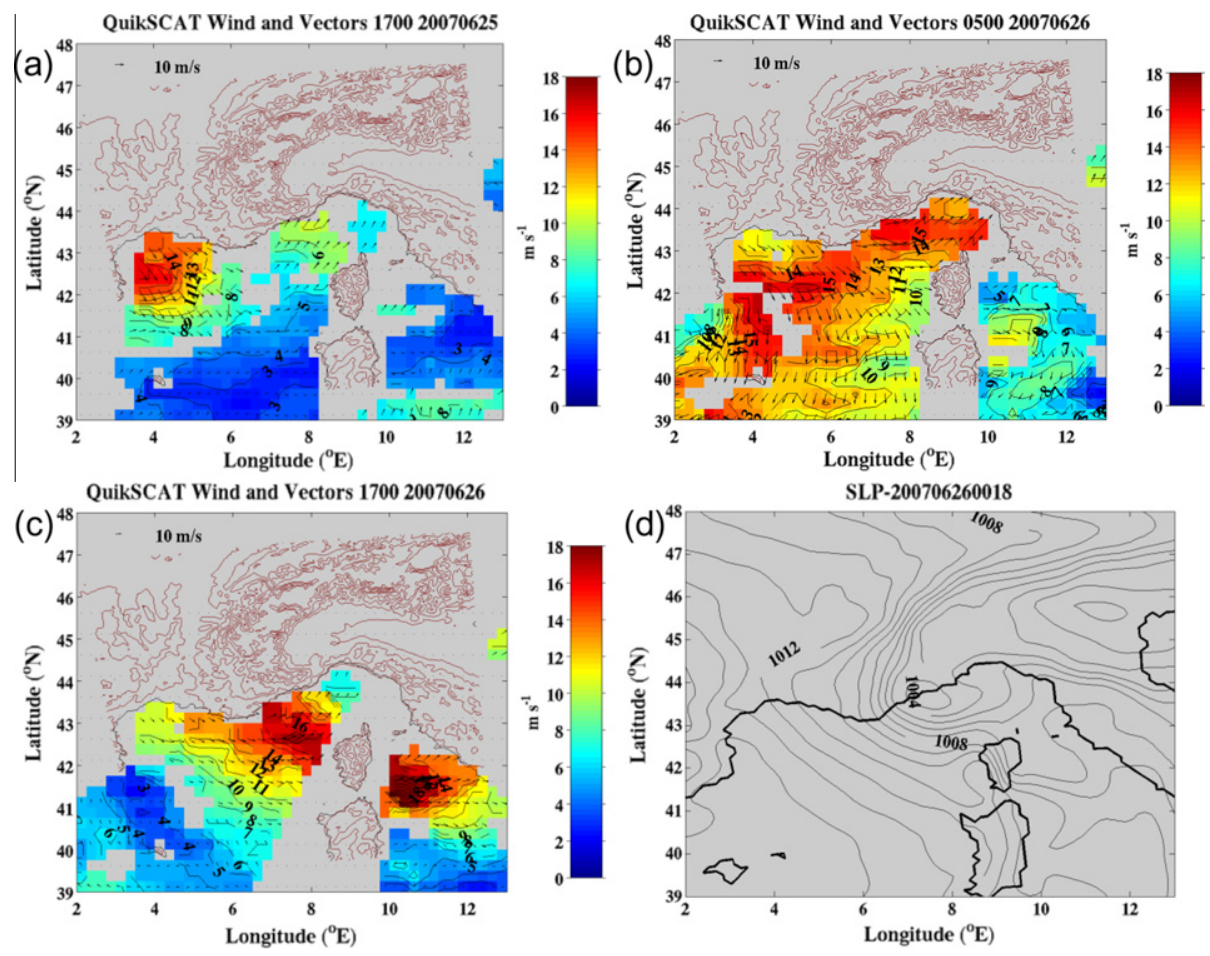

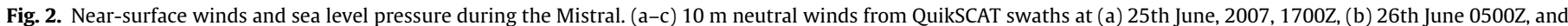

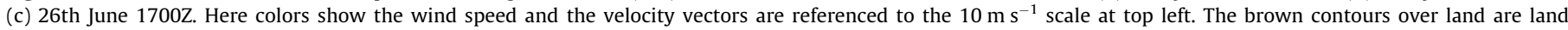

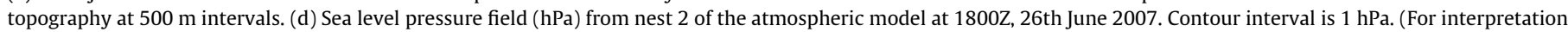
of the references to color in this figure legend, the reader is referred to the web version of this article.)
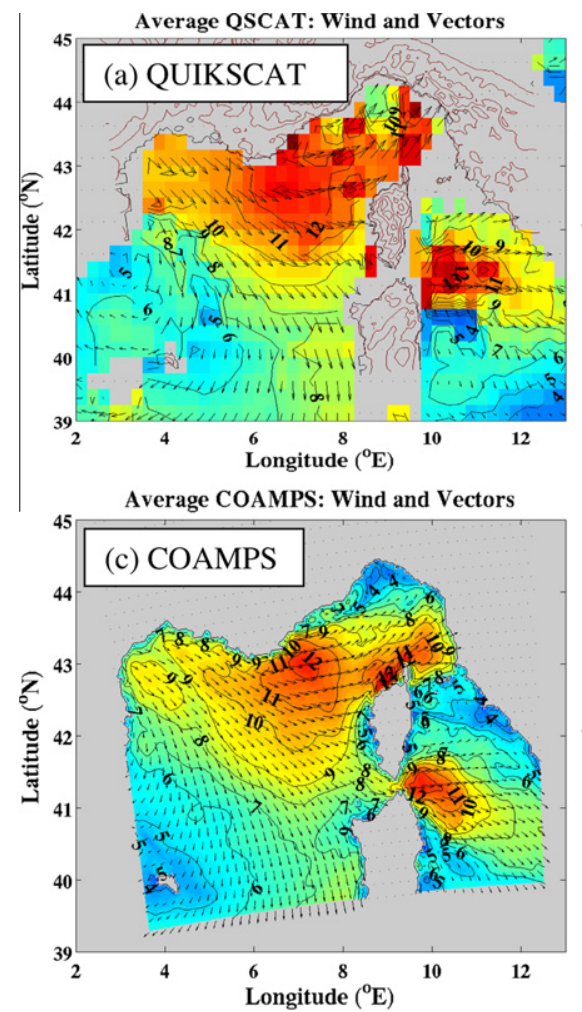
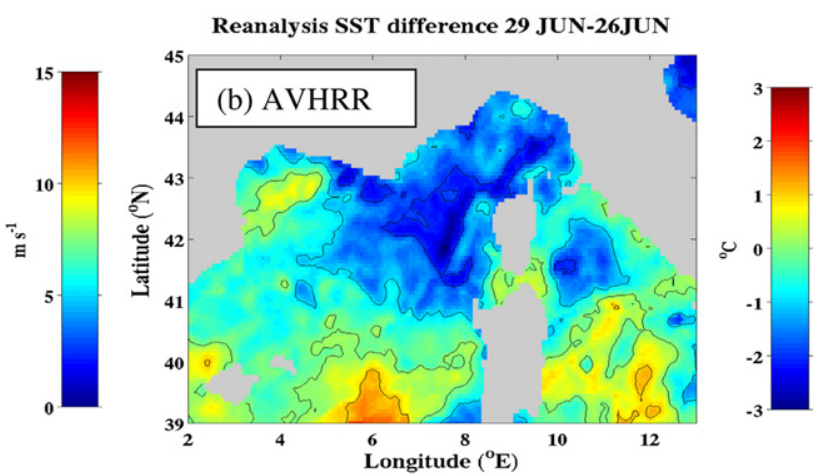

COAMPS 72 hour SST difference Exchange Nest

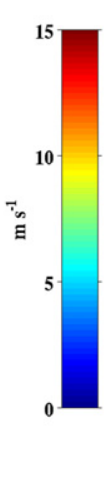

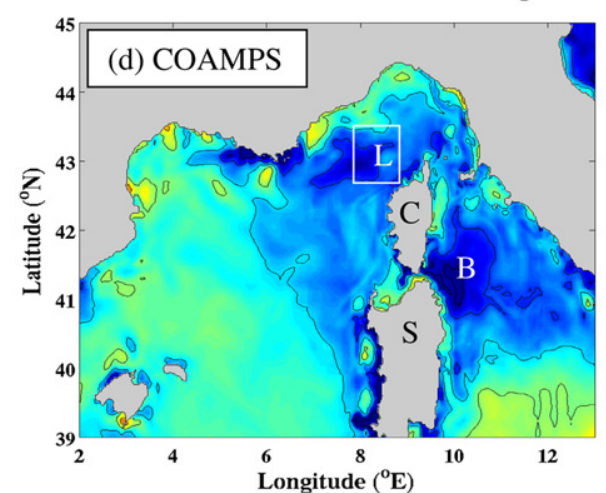

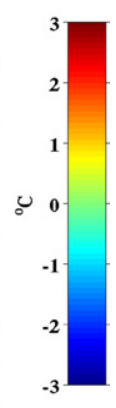

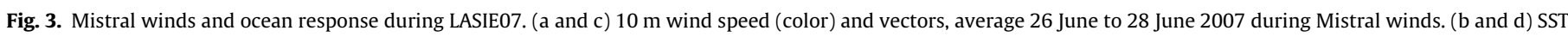

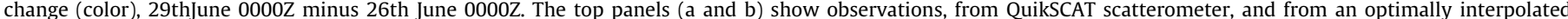

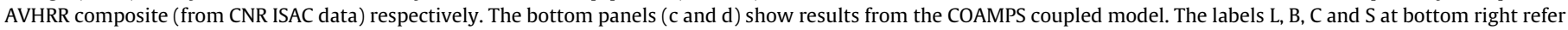
to Ligurian Sea, Strait of Bonifacio, Corsica and Sardinia respectively. 
Identical initial conditions for SST are used in both simulations, and no data assimilation is employed. Hence, differences that arise between the two experiments are due solely to the coupling that occurs during the run, and not due to initial differences in the SST field, or due to the influence of data assimilation. We refer to the atmospheric portion of the $U$ run (which includes the surface flux computation) as the uncoupled atmosphere (UA), and likewise the ocean part of the $U$ run as uncoupled ocean (UO).

Lateral boundary conditions for the atmospheric model come from the operational NOGAPS 1 degree model, 6 hourly output, whilst those for the ocean model also come 6 hourly from the global version of the NCOM, 1/8 degree model (Barron et al., 2006).

The initial conditions for these experiments come from these same global ocean and atmosphere models. To investigate the sensitivity of the results to the initial state, we compared the results of this study with two experiments having longer spin-up. The first was a preliminary experiment of the same nature as that described here, but using 3 day atmospheric spin-up (COAMPS atmospheric model with analysed SST at the surface) and a 10 day ocean spin up (NCOM forced by NOGAPS). The second was a month long coupled simulation detailed in Small et al. (2011), which began 16 days before the event studied here. The response of the ocean in these cases was qualitatively similar to that in the experiment discussed in this paper. In particular, the spatial scale and magnitude of the wind jets and of the SST cooling, and the occurrence of strong inertial waves, were comparable in all three experiments. Hence the conclusions of this paper are not sensitive to the spin-up.

\section{Coupled simulation of a summer Mistral event}

We first describe the time evolution of the Mistral event from observations and model results. The first observed signs of the wind event appear on the evening of the 25th June, when winds of over $15 \mathrm{~m} \mathrm{~s}^{-1}$ emanate from the Gulf of Lions in QuikSCAT data (Fig. 2a, a swath at 1800 Local Time or 1700Zulu (Z), 25th June), suggestive of an initial Tramontane or mixed Tramontane/Mistral event. On the morning of the 26th June, QuikSCAT data shows wind speeds of 10-15 $\mathrm{m} \mathrm{s}^{-1}$ over most of the Ligurian Sea (Fig 2b). By the evening of the 26th June (Fig. 2c and d) and throughout the 27 th June (not shown) a low pressure cell is simulated just west of the Gulf of Genoa on the coast with strong pressure gradients and winds up to $18 \mathrm{~m} \mathrm{~s}^{-1}$ north and west of Corsica and near the Strait of Bonifacio, ${ }^{2}$ and weaker winds in the Gulf of Lions. By the 28th June the winds have considerably weakened in both model and observations.

The complete event of 26th-28th June is summarized in Fig. 3. The 3-day average wind speed and velocity at $10 \mathrm{~m}$ from QuikSCAT reveals the winds up to $12-13 \mathrm{~m} \mathrm{~s}^{-1}$ over the Ligurian Sea associated with the Mistral (Fig. 3a). The wind directions and spatial distribution of wind speed extrema shown in Fig. 3a are very close to those seen in climatologies for the summer (see e.g. Fig. 3 of Pinardi and Masetti, 2000), demonstrating the dominance of this synoptic feature. The wind field in the COAMPS $C$ run reproduces the main features of the flow (Fig. 3c), in particular the locations of strongest winds in the central Ligurian Sea, north-east of Corsica, and east of the Strait of Bonifacio. However the model winds are weaker overall by $1-2 \mathrm{~m} \mathrm{~s}^{-1}$ compared to observations and are particularly weak in coastal regions such as the Gulf of Genoa, the head of the Gulf of Lions and the eastern Tyrrhenian Sea. This bias will be discussed later with respect to the ocean response.

The 3-day average of observed and modeled Ekman pumping (EP) velocities are shown in Fig. 4a and b, respectively. (Here the EP is multiplied by $(-1)$ so that positive values denote anticyclonic

\footnotetext{
2 This narrow strait separates Corsica and Sardinia.
}
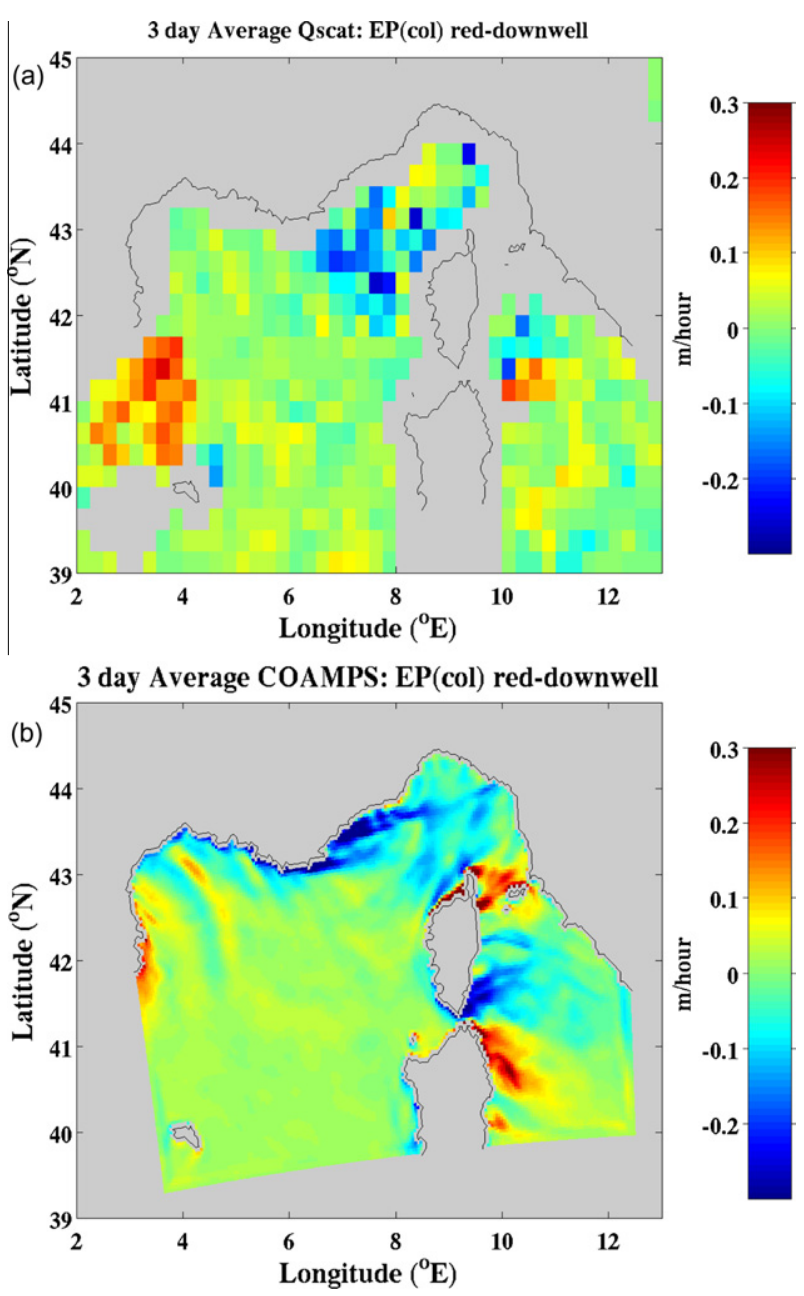

Fig. 4. As for Fig. 3a and c, but showing negated Ekman pumping velocity ( $\mathrm{m} \mathrm{h}^{-1}$, positive downwards convention such that red areas denote downwelling) (a) from QuikSCAT, (b) from the coupled model.

curl and downwelling in the ocean.) Despite the different resolutions in QuikSCAT and the model atmospheric grid, it is still possible to make comparisons between the fields. Both observations and model show the cyclonic curl, inducing upwelling, in the Ligurian basin. A north-south cyclonic-anticyclonic dipole occurs just east of the Strait of Bonifacio (the nodal line of this dipole appears further south in the model). Anticyclonic curl south and west of the Gulf of Lions is seen between $2^{\circ} \mathrm{E}$ and $4^{\circ} \mathrm{E}$, just visible on the edge of the model domain, and there is a hint that the satellite data shows a thin 'filament' of anticyclonic curl offshore of the Gulf of Lions, which is more clearly seen in the model field (Fig. 4a and b). This latter feature, which corresponds to the boundary between the Mistral and Tramontane jets, is possibly related to potential vorticity banners (Aebischer and Schär, 1998). The model EP also shows anticyclonic curl east of the north-eastern tip of Corsica, in a region unfortunately obscured by the QuikSCAT land mask. The significance of these structures in the Ekman pumping field will be discussed in more detail in Section 6.1.

\section{Response of the upper ocean}

\subsection{Sea surface temperature}

The initial SST condition for the northern part of the outer model domain is shown in Fig. 5a. It is characterized by temperatures of 

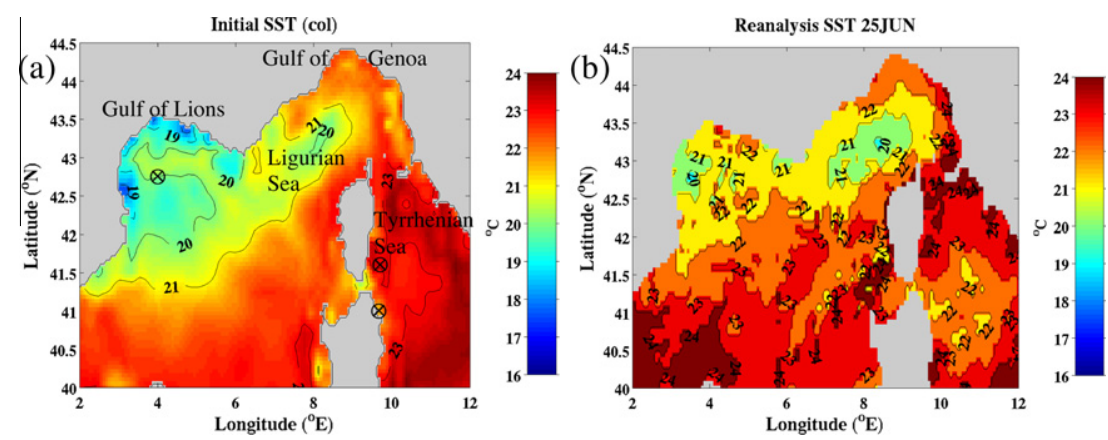

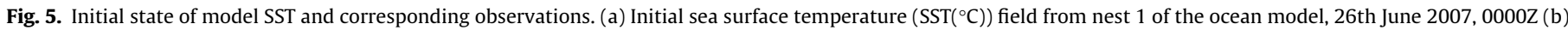
reanalysis SST from CNR ISAC for the 25th June.
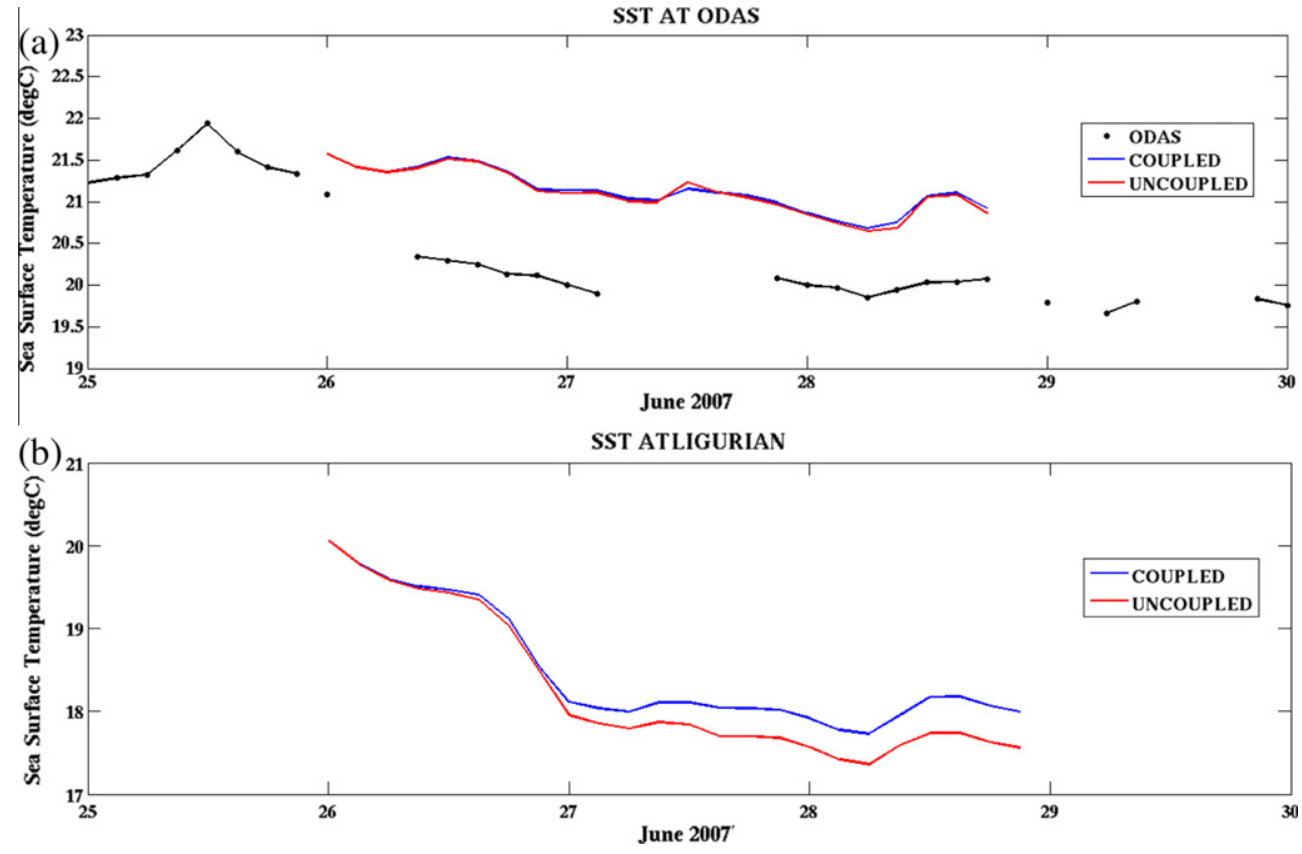

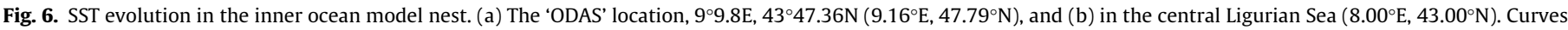

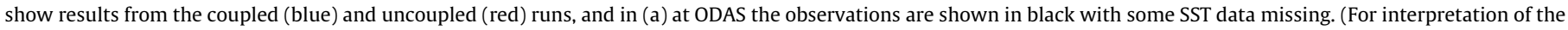
references to color in this figure legend, the reader is referred to the web version of this article.)

$21-24^{\circ} \mathrm{C}$ over much of the north-west Mediterranean Sea, but with cooler temperatures, down to $18{ }^{\circ} \mathrm{C}$, in the Gulf of Lions, as a result of previous Mistral and/or Tramontane events. Reanalysis data from the CNR-ISAC SST satellite product compiled for the 25th June shows a similar spatial SST distribution, but is warmer than the model by over $1^{\circ} \mathrm{C}$ in the Gulf of Lions and west of Corsica and Sardinia (Fig. 5b).

The ocean response to the winds is first illustrated by the change in SST between 0000Z 26th June and 0000Z 29th June, from the analysed infrared satellite SST data (Fig. 3b). The ocean cools by over $1^{\circ} \mathrm{C}$ over $72 \mathrm{~h}$ in most of the Ligurian Sea and northern Tyrrhenian Sea, with the strongest cooling, between $2{ }^{\circ} \mathrm{C}$ and $3{ }^{\circ} \mathrm{C}$, to the north and west of Corsica, and east of the Strait of Bonifacio (referenced locations are shown in Fig. 3d). In general the ocean cools more in the regions of strongest winds, as one might expect from a simple one-dimensional mixed layer response, with the exception of the western Gulf of Lions where there is some weak warming despite reasonably strong winds. The coupled simulation reproduces these broad spatial patterns and magnitude of the SST response to the strong winds (Fig. 3d): some localized differences are discussed next.
There are patches of intensified cooling along the east and south-east coast of the Gulf of Lions in observations (Fig. 3b): here the wind velocities are parallel to the coast (Fig. 3a), giving rise to offshore Ekman transport and consequent coastal upwelling. Both the observations and the model (Fig. 3d) show greatest upwelling along the coast of the eastern Gulf (seen also in the study of summer upwelling by Millot (1979) and Millot and Wald (1981)), while the model upwelling extends further east than observed (coastal winds in the model east of the Gulf of Lions are more parallel to the coast than seen in QuikSCAT). Upwelling at the head of the Gulf is also more prominent in observations, which may relate to the weak model winds in that location as discussed above. In addition, Millot and Wald (1981) noted downwelling in the south-west part of the Gulf, roughly where Fig. 3b and d show very weak cooling and some warming.

East of the Strait of Bonifacio, the cooling in observations and model is reminiscent of the filaments identified by Salusti (1998) and Perilli et al. (1995) as a response to Mistral winds accelerated through the Strait (see Section 6 for more details). This is related to the 'Tyrrhenian Eddy', a cyclonic, cold-cored eddy that lies east of the Strait of Bonifacio (Schiano et al., 1993; Artale et al., 1994; 
Perilli et al., 1995; Salusti, 1998; Bignami et al., 2008). These authors suggest that this is the dominant part of a north/south cyclonic/anticyclonic gyre couplet, driven by the strong winds through the Strait of Bonifacio and the consequent Ekman pumping dipole (see Fig. 4). The model SST response is stronger than observed by about $1{ }^{\circ} \mathrm{C}$, and extends further to the west and through the Bonifacio Strait (Fig. 3b and d). The lack of a strong response seen in the Strait in observations could relate to land-masking of satellite data in that narrow $(11 \mathrm{~km})$ channel.

Close inspection of Fig. $3 \mathrm{~b}$ and $\mathrm{d}$ ) reveals that offshore of the Gulf of Genoa, COAMPS underestimates the reduction in SST over 3 days relative to the AVHRR observations $\left(0-1{ }^{\circ} \mathrm{C}\right.$ in model compared to $1-2{ }^{\circ} \mathrm{C}$ in observations). The time evolution of the sea surface temperature at the ODAS mooring showed that the temperature at $1 \mathrm{~m}$ dropped from $21.3^{\circ} \mathrm{C}$ in the evening of the 25th June to $19.9^{\circ} \mathrm{C}$ early on the 27th June (Fig. 6a, black line with symbols), consistent with the satellite data. In contrast both the coupled $C$ and uncoupled (UO) model show a more gradual decline at this location, dropping by about $0.6^{\circ} \mathrm{C}$ over the same time period (Fig. 6a, blue and red lines). The fact that the coupled and uncoupled ocean runs are almost indistinguishable at this location will be discussed further below.

The model underestimation of the SST response at ODAS was discussed in Small et al. (2011): mixed layer model experiments showed that two factors made significant contributions to the difference: (i) winds that were too weak in COAMPS (compare Fig. 3a and $\mathrm{c}$ in the Gulf of Genoa), and (ii) an underestimate of the mixing by NCOM. Another possible reason for the model SST bias at ODAS, not discussed in Small et al. (2011), is differences in the initial ocean stratification. Fig. 1 shows the temperature and density structure from five conductivity-temperature-depth profiles taken early on the 26th June close to the ODAS mooring during the LASIE07 experiment. Their mean is shown in red and, for comparison, the initial condition for the model in the same location is shown in black. The model profile has a deeper mixed layer and weaker vertical gradient in the upper thermocline than the observations (the LASIE07 observations were not assimilated into the global NCOM model which provided initial conditions). In the model the $19.9{ }^{\circ} \mathrm{C}$ water is located $5 \mathrm{~m}$ deeper than in the mean CTD profile (see Fig. 1a), which may partly explain why the model does not bring such cold water to the surface.

In the central Ligurian Sea, cooling reaches $2-3{ }^{\circ} \mathrm{C}$ in both observations and model (Fig. 3b and d), although the spatial patterns are somewhat different: the strongest response in observations is west of Corsica whereas in the model it is north of Corsica. This may relate to differences in the wind field, with a stronger southward offshore extension of the wind jet in the observations (Fig. 3a) compared to COAMPS (Fig. 3c) which has a jet more attached to the Provence coast. A time series at $8^{\circ} \mathrm{E}, 43^{\circ} \mathrm{N}$, where a cooling of about $2{ }^{\circ} \mathrm{C}$ is seen in observations over 3 days (Fig. $3 \mathrm{~b}$ ), reveals that most of the model cooling occurs in the first $24 \mathrm{~h}$, about $2^{\circ} \mathrm{C}$ (Fig. 6b), when wind speeds increase from 10 to $16 \mathrm{~m} \mathrm{~s}^{-1}$, and surface stress reaches $0.5 \mathrm{Nm}^{-2}$ (not shown), reasonably consistent with QuikSCAT (Fig. 2a-c) and the UO run cools more (by about $0.5^{\circ} \mathrm{C}$ ) over the 3 day period (Figs. $6 \mathrm{~b}$ and $9 \mathrm{~d}$ ).

\subsection{Surface current response}

The circulation in the Ligurian Sea (locations are marked on Fig. 5a) is closely tied to the influence of the Mistral. Crépon et al. (1989) hypothesise that a geostrophic adjustment to deep water formation in winter gives rise to a basin scale cyclonic gyre, which is present year round. Herbaut et al. (1997) find that cyclonic wind stress curl, east of the Mistral jet axis, helps to maintain the cyclonic circulation. Strong currents associated with the cyclonic gyre flow around the edge of the basin, such as the
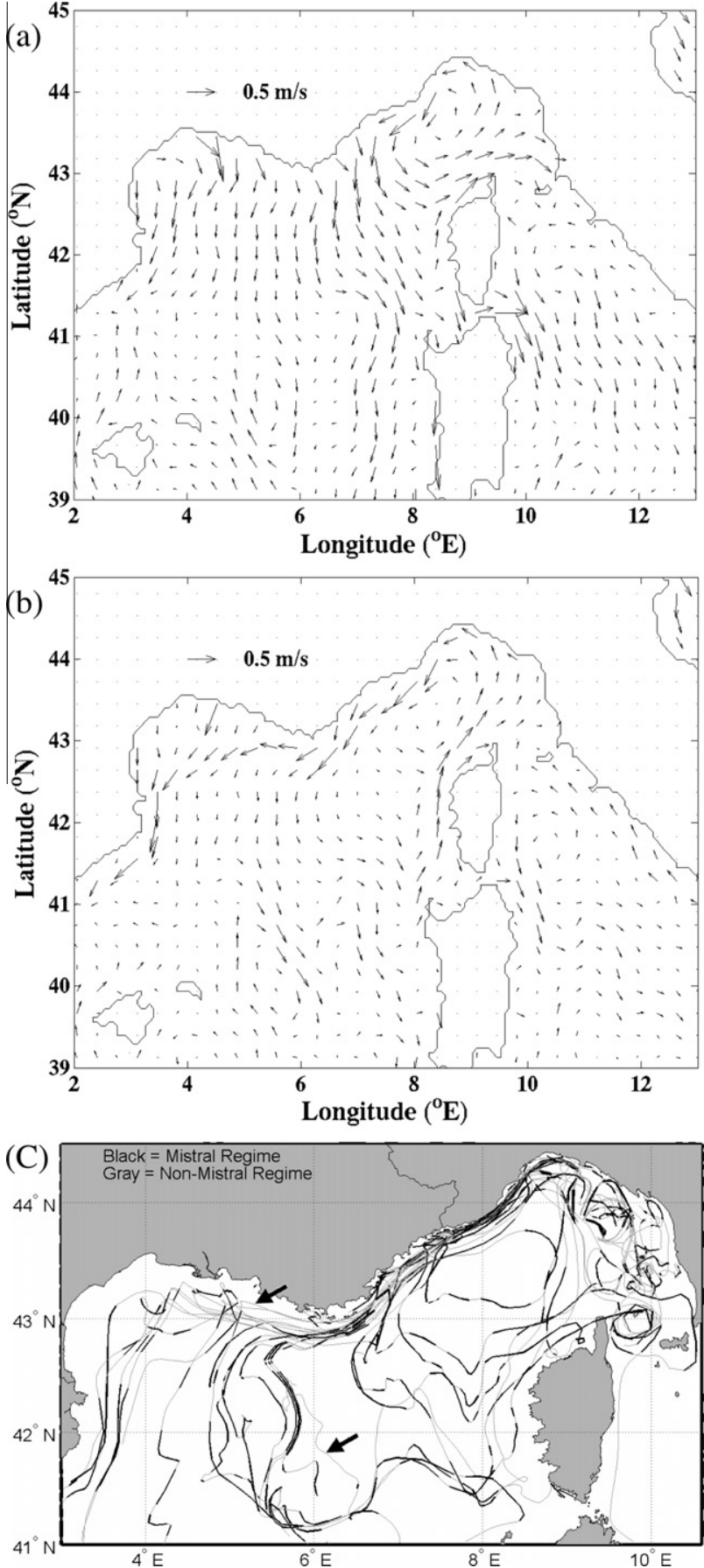

Fig. 7. (a) Ocean surface currents averaged over 3 days of coupled run, from ocean outer nest (b) surface currents from a 1 month simulation described in Small et al. (2011). (c) Observations from drifters reproduced from Poulain et al. (submitted for publication). Black lines denote drift during periods of Mistral: grey lines are from all other times.

Liguro-Provencal or Northern Current, and west Corsican current (Poulain et al., submitted for publication; Carniel et al., 2002; Schroeder et al., 2011).

The strong winds during the Mistral case study drive a significant surface current response. The surface ocean currents averaged over the 3 days of simulation are shown in Fig. 7a. For reference, the corresponding currents from a full month simulation of the COAMPS model (identical to the model used here excepting that it was initialized 16 days earlier, and incorporated data assimilation in the atmosphere, as described in Small et al. (2011)), is 

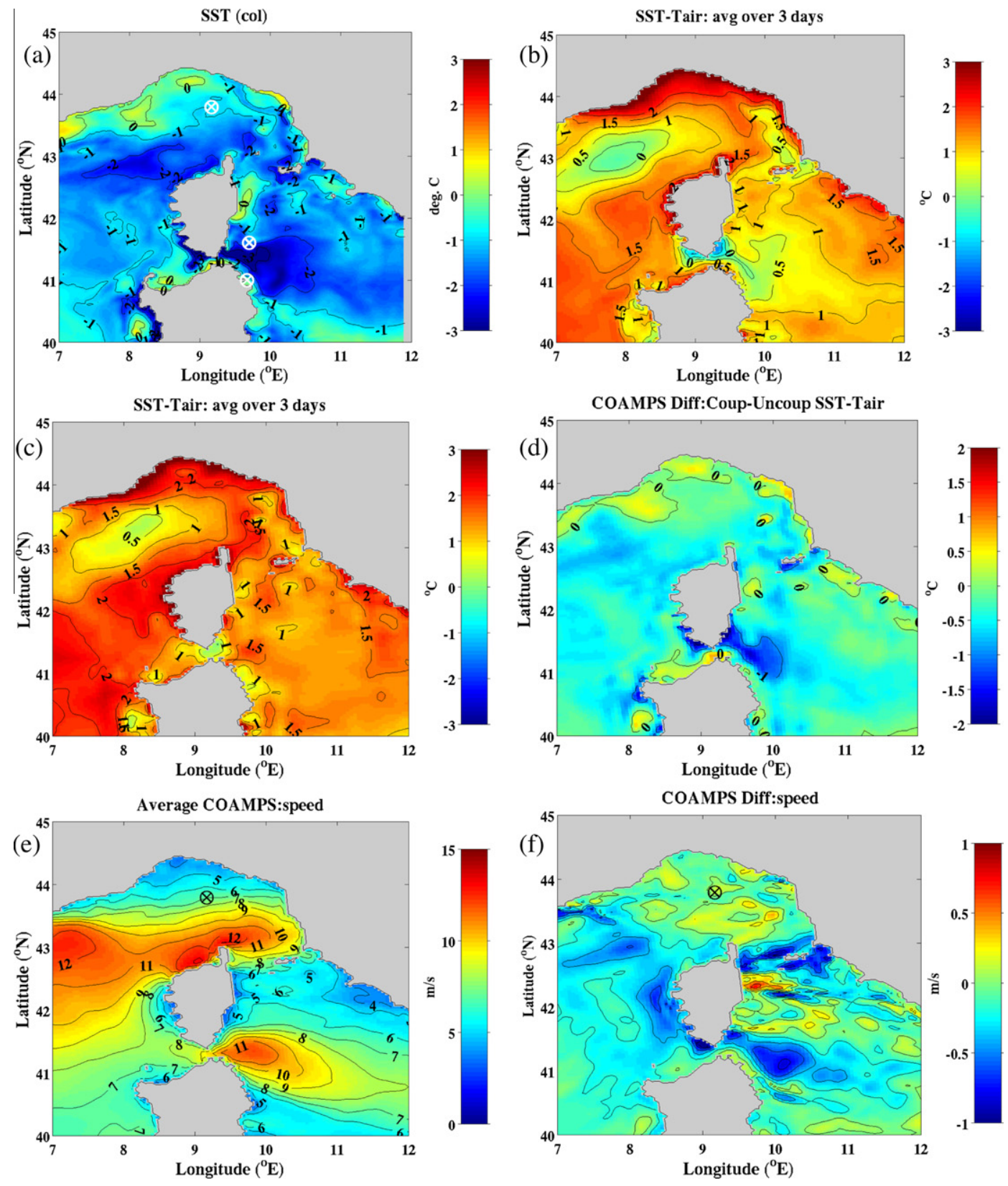

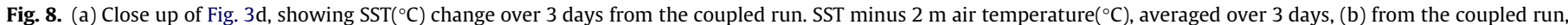

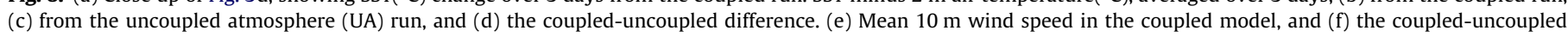
difference in $10 \mathrm{~m}$ wind speed.

shown in Fig. 7b. Comparing the two, we see that in response to the Mistral winds, flow is more offshore in the Gulf of Lions and the northern coast of the Ligurian Sea. A tight eddy-like cyclonic gyre is formed to the north of Corsica during the Mistral (Fig. 7a), in contrast to the broad Ligurian Sea gyre seen in the 1 month simulation, with weak flow on its western and southern flank (Fig. 7b). The Northern or Liguro-Provencal current is much less apparent during the Mistral events. Strong flow is also seen through the Strait of Bonifacio (Fig. 7a) in response to the jet-like winds (Fig. 3a and c).

The modeled currents are reasonably consistent with those derived from an analysis of drifter data by Poulain et al. (submitted for publication). In that paper, multiple drifter deployments, mostly starting in June 2007 but lasting for a number of months afterwards, revealed the near-surface circulation in the Ligurian Sea. These authors classified the data into periods of Mistral winds and other periods (Fig. 7c). According to the authors, the recirculation or 'short-cutting' segment of the circulation, namely the offshore drift occurring somewhere between the French/Italian border and the Gulf of Lions, occurs only during Mistral periods. This is consistent with a strong offshore component of the currents in the Mistral model simulation (Fig 7a) in contrast to the strong alongshore flow (extending right across the Gulf of Lion), and weak recirculation in the whole-month-average (Fig. 7b). Millot and Wald (1980) also showed that the westward extent of the Northern Current was greater when Mistral winds were not blowing.

\section{Air-sea fluxes and the importance of coupling}

The uncoupled atmosphere (UA) does not see the temporal change in SST discussed in Section 4.1, so we may expect a large difference in the fluxes between the two experiments. In particular, 

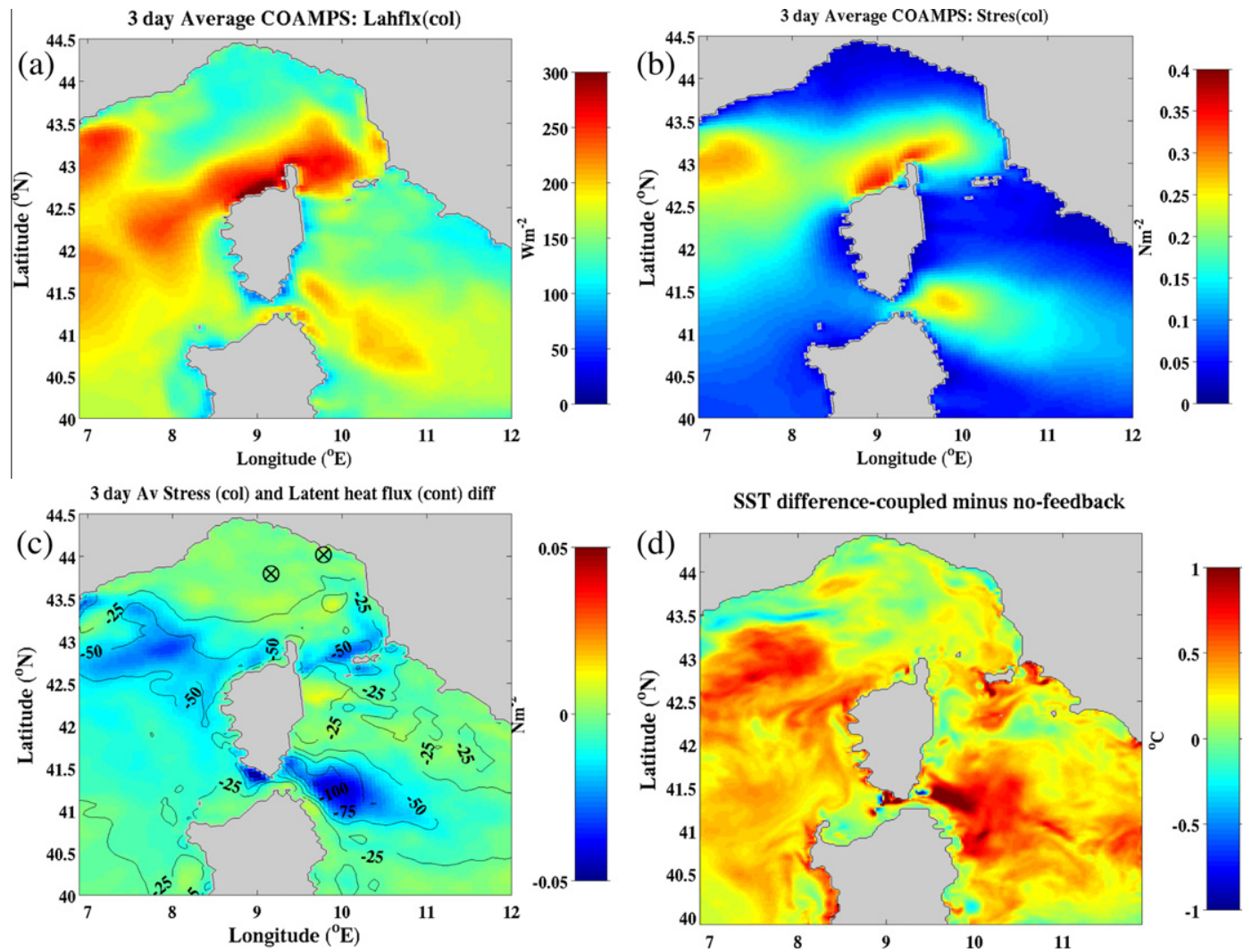

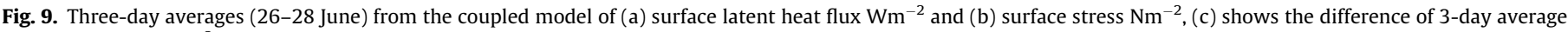

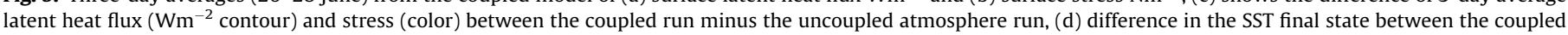
run and uncoupled ocean run.
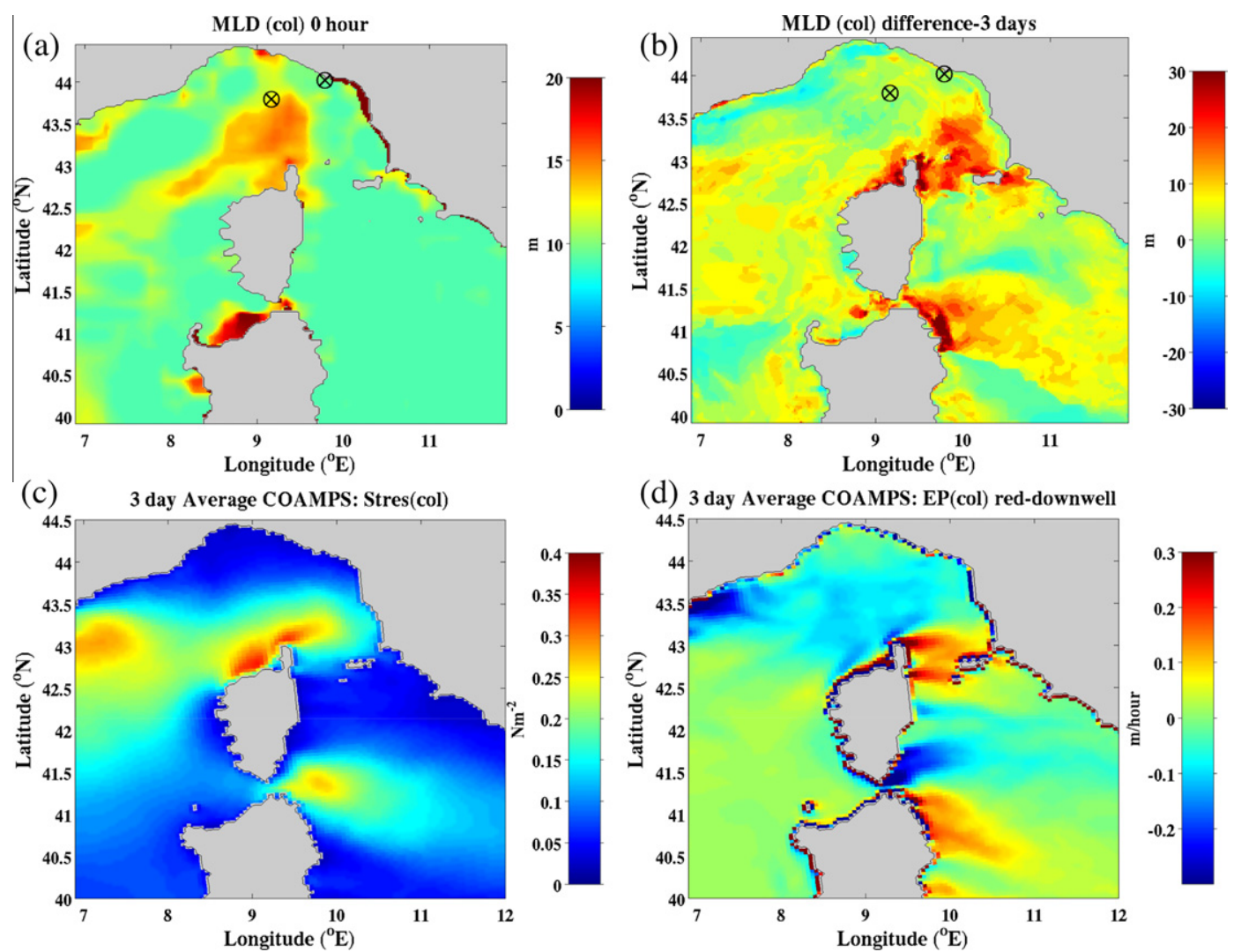

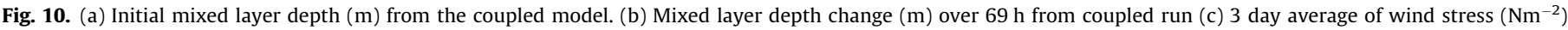
repeated from Fig. 9b. (d) The 3 day average of negated Ekman pumping velocity ( $\mathrm{m} \mathrm{h}^{-1}$, positive downwards convention such that red areas denote downwelling). 
in the regions of cooling SST in the coupled run (see Fig. 8a for a close-up), a lower value of sea-air temperature difference is likely, because of the reduction of SST (although some compensation will occur as the air temperature adjusts to the SST). Indeed, plots of the sea-air temperature difference $\Delta T=T_{s}-T_{a}$, where $T_{s}$ is the SST and $T_{a}$ is the near-surface air temperature (Fig. $8 \mathrm{~b}$ and $\mathrm{c}$ ), indicate that $\Delta T$ was lower by up to $1{ }^{\circ} \mathrm{C}$ in the coupled run compared against the uncoupled run, in the regions of strongest SST cooling (as shown in the difference map Fig. 8d).

The surface latent heat flux averaged over the 3 day $C$ run reaches over $200 \mathrm{Wm}^{-2}$ (Fig. 9a) where the winds are strong (Fig. 8e). In this $C$ run, the latent heat flux is less than that in the UA run, by $50-100 \mathrm{Wm}^{-2}$ (Fig. 9c, contours), or $25-50 \%$, in the regions of strongest SST cooling. The sensible heat fluxes show similar spatial patterns of the differences which reach up to $30 \mathrm{Wm}^{-2}$, a $100 \%$ change (not shown), with again the UA run fluxing more heat out of the ocean. The surface stress reaches up to $0.25 \mathrm{Nm}^{-2}$ in the $C$ run (Fig. 9b), about $0.025-0.05 \mathrm{Nm}^{-2}$ less than in the UA run (Fig. 9c, colors), or about a $10-20 \%$ reduction.

The differences in heat fluxes are due to a combination of the change in stability between the experiments, as well as differences in wind speeds. A change in $\Delta T$ of $1^{\circ} \mathrm{C}$ between the experiments is comparable to the typical magnitude of $\Delta T$ in the individual experiments: thus leading to the $100 \%$ changes in sensible heat flux. Further, cooler SST in the coupled $C$ run would mean a smaller saturation specific humidity at that value of $\operatorname{SST}\left(q_{s a t}\left(T_{s}\right)\right)$, so the difference $\Delta q=q_{\text {sat }}\left(T_{s}\right)-q_{a}\left(T_{a}\right)$, where $q_{a}$ is air humidity, is likely to decrease, contributing to lower latent heat flux in the coupled run. A simple example can quantify this: for an SST of $23^{\circ} \mathrm{C}$, a relative humidity of $80 \%$, and air temperature of $22^{\circ} \mathrm{C}, \Delta q \sim 4.3 \mathrm{~g} \mathrm{~kg}^{-1}$. If the SST is reduced by $2{ }^{\circ} \mathrm{C}$ to $21^{\circ} \mathrm{C}$ and all else remains the same, $\Delta q \sim 2.3 \mathrm{~g} \mathrm{~kg}^{-1}$. If we take into account adjustment of air temperature towards the SST, and assume $T_{a}$ drops by $1^{\circ} \mathrm{C}$ to $21^{\circ} \mathrm{C}$, then $\Delta q \sim 3.0 \mathrm{~g} \mathrm{~kg}^{-1}$. In other words, $\Delta q$ will be reduced by a factor of about 1.5-2 as a result of the SST reduction, and this could lead to a corresponding difference in latent heat flux, which is consistent with the $25-50 \%$ latent heat flux reduction quoted above.
The time-averaged $10-\mathrm{m}$ wind speed differences between the runs reaches up to $\pm 0.5 \mathrm{~m} \mathrm{~s}^{-1}$, or about $5 \%$ of the average wind speed (Fig. 8f). While these changes in wind speed are much less important to the modifications in heat fluxes than the change in SST, $\Delta q$ and $\Delta T$, they do have a greater effect on stress. At wind speeds of $10 \mathrm{~m} \mathrm{~s}^{-1}$, a wind speed change of $0.5 \mathrm{~m} \mathrm{~s}^{-1}$ would create about a $10 \%$ change in stress. By comparison the effect of a $1{ }^{\circ} \mathrm{C}$ change of $\Delta T$ on drag coefficient at these wind speeds is less than 10\% (e.g. Liu et al., 1979, their Fig. 12).

When the reduced fluxes (heat flux and stress) in the coupled $C$ run act on and interact with the ocean model, the resultant cooling of SST is diminished, relative to the uncoupled ocean simulation UO where the fluxes are not modified by changes in SST. The surface temperature difference due to coupling, $\delta T$, is shown in Fig. 9d and approaches $1^{\circ} \mathrm{C}$ in the wind jet locations. This may be compared against an estimate for an idealized case of a slab mixed layer. In that case the mixed layer temperature change due to coupling, $\delta T_{m}$, is given by $\delta T_{m}=\delta Q \cdot \Delta t / \rho c_{p} H$, where $\delta Q$ is the change in net surface heat flux due to coupling, $\rho$ the water density, $c_{p}$ the specific heat capacity of water, $\Delta t$ the time duration of interest (3 days here), and $H$ the mixed layer depth. For the $100 \mathrm{Wm}^{-2}$ reduction in latent heat flux east of Bonifacio due to coupling (Fig. 9c), and for a typical value of $H=10 \mathrm{~m}$, this would result in a temperature change of $\delta T_{m} \sim 0.65{ }^{\circ} \mathrm{C}$, with the coupled model being warmer, quite consistent with Fig. 9d.

In the Gulf of Genoa, and specifically at the ODAS location, the SST difference between the $\mathrm{C}$ and $\mathrm{UO}$ simulations is small $\left(\delta T<0.25^{\circ} \mathrm{C}\right)$ (Figs. 6a and 9d). The reason for this is as follows. Firstly, the winds in the COAMPS model are too weak (Fig. 3a and $\mathrm{c}$ ), so that the SST response in the coupled model is small $\left(<1^{\circ} \mathrm{C}\right.$, Figs. $6 \mathrm{a}$ and $\left.8 \mathrm{a}\right)$. As a consequence, the differences in $\Delta T$ and in surface fluxes at this location between the $C$ run and the UA run are also small (Figs. 8d and 9c). This in turn leads to the small difference between $\mathrm{C}$ and UO SST (i.e. $\delta T$ ). Note that even in regions with larger wind speeds and SST response in the model the $\delta T$ value can be small. For example, along the meridional section at $9^{\circ} \mathrm{E}$ from the north Corsica coast to $43.5^{\circ} \mathrm{N}$, just south of
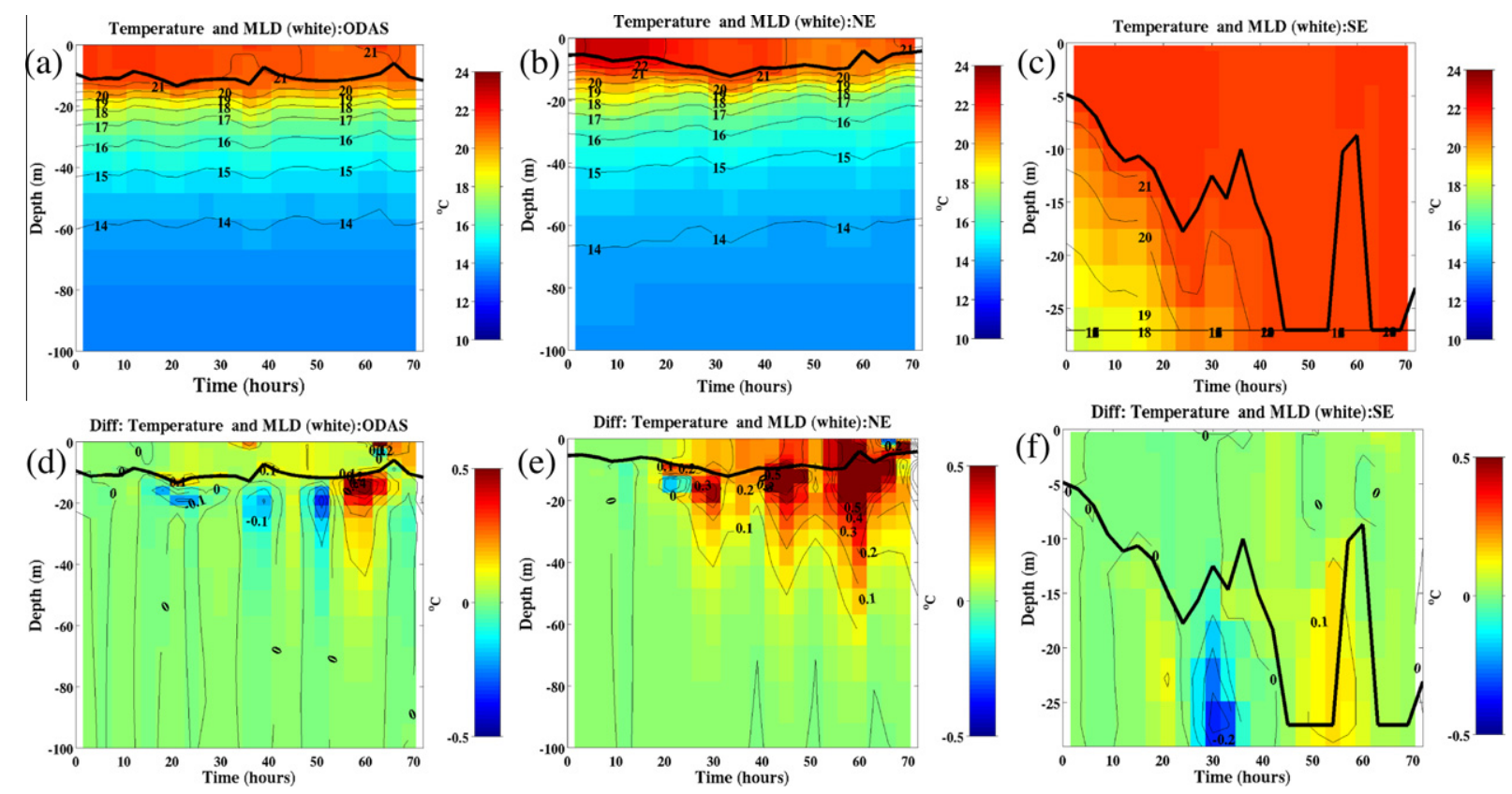

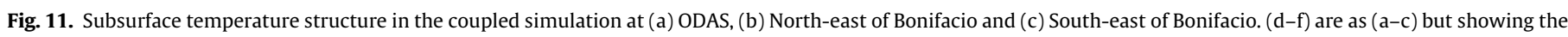

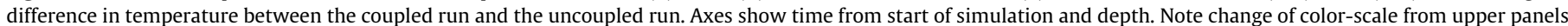
to lower panels, and different depth range in (c and f). The thick black line is the mixed layer depth in the coupled case. 
ODAS, mean wind speeds in the model vary from $12 \mathrm{~m} \mathrm{~s}^{-1}$ to $8 \mathrm{~m} \mathrm{~s}^{-1}$ (Fig. 8e) whilst the SST response ranges from $1^{\circ} \mathrm{C}$ to $2^{\circ} \mathrm{C}$ (Fig. 8a). However $\delta T$ is less than $0.25^{\circ} \mathrm{C}$ all along this section (Fig. 9d). This would suggest that the model bias does not necessarily influence the conclusion that coupling has a minimal effect at ODAS. Instead, close inspection of Figs. 8d and $9 \mathrm{c}$ and $\mathrm{d}$ show that coupling is important to SST only when the air-sea temperature difference $\Delta T$ is reduced by at least $0.5^{\circ} \mathrm{C}$.

\section{Ocean subsurface response}

\subsection{Ocean mixed layer depth and stratification}

In the regions of strongest winds shown in Fig. 3a and c, the initial mixed layer depth in the model is shallow $(15 \mathrm{~m}$ or less, Fig. 10a), a situation conducive to cooling by entrainment and/or upwelling. Hence the upper ocean stratification changes significantly during the wind event.

After the 3-day period of strong winds, the mixed layer depth increases up to $30 \mathrm{~m}$ or more in some regions in the $\mathrm{C}$ run (Fig. 10b). The change in mixed layer depth is a combination of two factors: high wind stress (Fig. 10c) leading to entrainment and mixed layer deepening, and the Ekman pumping (EP) effect due to curl of the wind stress (a close up of Fig $4 \mathrm{~b}$ is shown in Fig. 10d). This combination of factors leads to the mixed layer depth increase being largest east and south of the Strait of Bonifacio, and around the north-east tip of Corsica (Fig. $10 b^{3}$ ). The magnitude of the Ekman pumping velocities south and east of Bonifacio and north-east of Corsica (up to $0.3 \mathrm{~m} \mathrm{~h}^{-1}$ (Fig. 10d), or about $21 \mathrm{~m}$ over 3 days) is consistent with the total mixed layer depth change of 20-30 m (Fig. 10b) over 3 days.

The changes in stratification are further illustrated by the time evolution of temperature structure in the $C$ run at three locations marked by circled crosses in Fig. 8a: (i) the ODAS mooring, (ii) a site north-east of the Strait of Bonifacio (referred to by NE here), and (iii) a site south-east of the Strait in shallow water (referred to by SE). At ODAS (Fig. 11a) there are oscillations of the mixed layer depth and of the thermocline, but no overall trend of upwelling or downwelling. At NE, the thermocline steadily upwells although the mixed layer initially deepens before later shoaling (Fig. 11b). However at $\mathrm{SE}$, the mixed layer rapidly deepens from $5 \mathrm{~m}$ depth towards the bottom depth of $30 \mathrm{~m}$ before undergoing oscillations (Fig. 11c). Hence the subsurface temperature structure is consistent with upwelling north and east of the Strait of Bonifacio, downwelling to its south and east, and little overall vertical motion at ODAS.

Differences in the subsurface structure between the $\mathrm{C}$ and UO simulations are most evident at NE, where the SST cooling is strong. Here the coupled model is warmer than the uncoupled run by over $0.5^{\circ} \mathrm{C}$ throughout the mixed layer and to depths of up to $50 \mathrm{~m}$ (Fig. 11e). In contrast the temperature differences at ODAS are patchy and mostly below the mixed layer (Fig. 11d) and at SE they are confined to near the bottom (Fig. 11f). A spatial map of mixed layer depths at the end of the $C$ and $U O$ simulations reveal that they differ by less than $3 \mathrm{~m}$ over the region of interest (not shown).

\subsection{Ocean heat budget}

In order to more fully understand the near-surface ocean temperature response, a heat budget was performed at the three locations marked in Fig. 8a (ODAS, NE, and SE). The heat budget analysis was performed over the first $69 \mathrm{~h}$ of the run, for the outer,

\footnotetext{
${ }^{3}$ We use the Kara et al. (2000) algorithm to detect mixed layer depth, beginning at $7 \mathrm{~m}$ depth to avoid diurnal effects. Thus the inferred reductions in mixed layer depth will necessarily be small in many regions where the initial mixed layer depth is around $10 \mathrm{~m}$ or less.
}
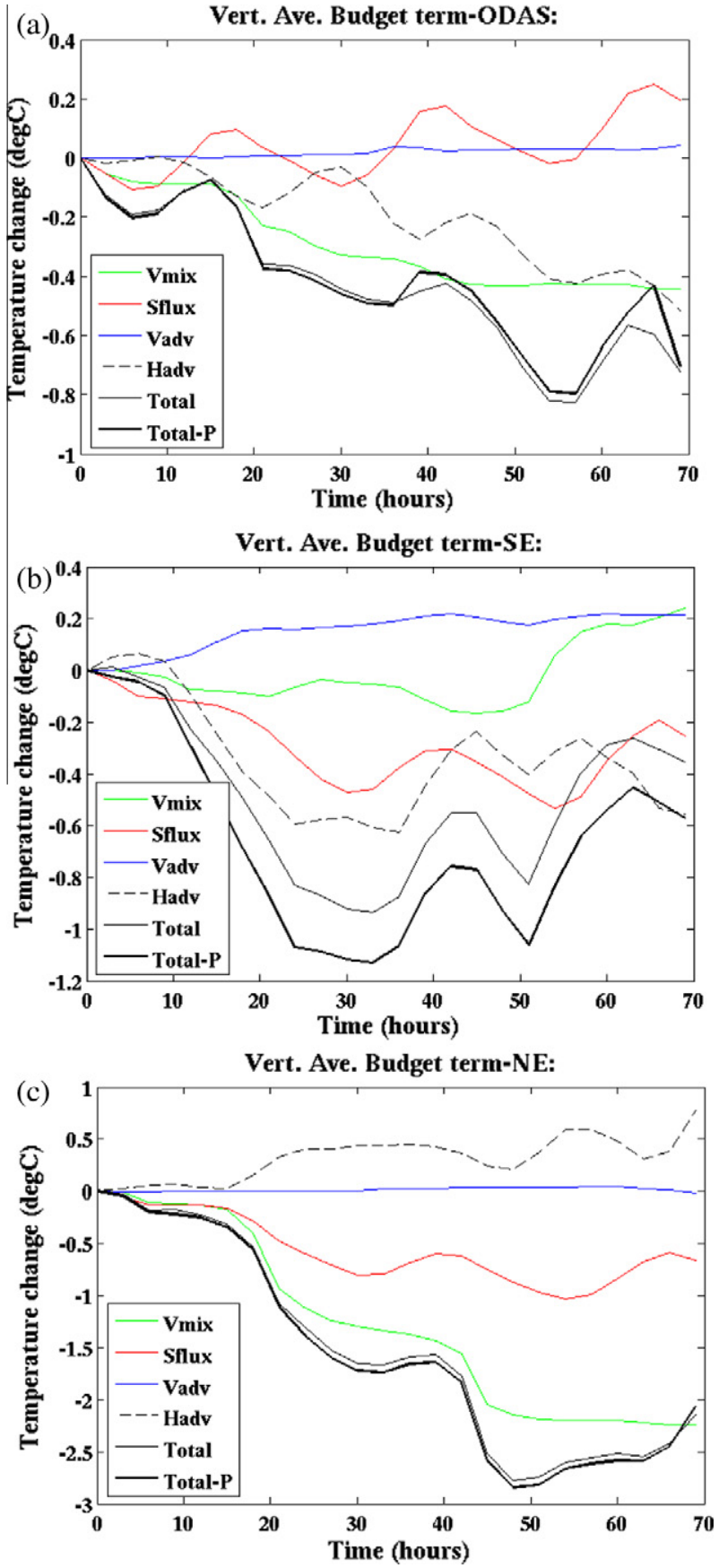

Fig. 12. Timeseries of budget terms vertically averaged to the mixed layer depth at (a) ODAS, (b) South-east of Bonifacio, (c) North-east of Bonifacio (see text for details). Here Vmix is vertical mixing, Sflux is net total surface flux term (comprising net radiation, short and longwave, sensible and latent heat flux), Vadv is the vertical advection term, Hadv is the horizontal advection, total is the total temperature change from all budget terms: Total-P is the temperature change computed from model output temperature profiles.

$6 \mathrm{~km}$ ocean nest of the $\mathrm{C}$ run (note there are small differences in the magnitude of SST cooling compared to the inner nest cooling shown in Fig. 8a). At these locations, the heat budget is performed at each depth, then a depth average is made to the base of the mixed layer.

The major terms of the heat budget are the contributions due to surface heat flux, vertical mixing, horizontal advection and vertical advection. The sum of the temperature change due to these terms and the much smaller horizontal mixing term is shown as the solid black lines in Fig. 12. This may be compared to the temperature 

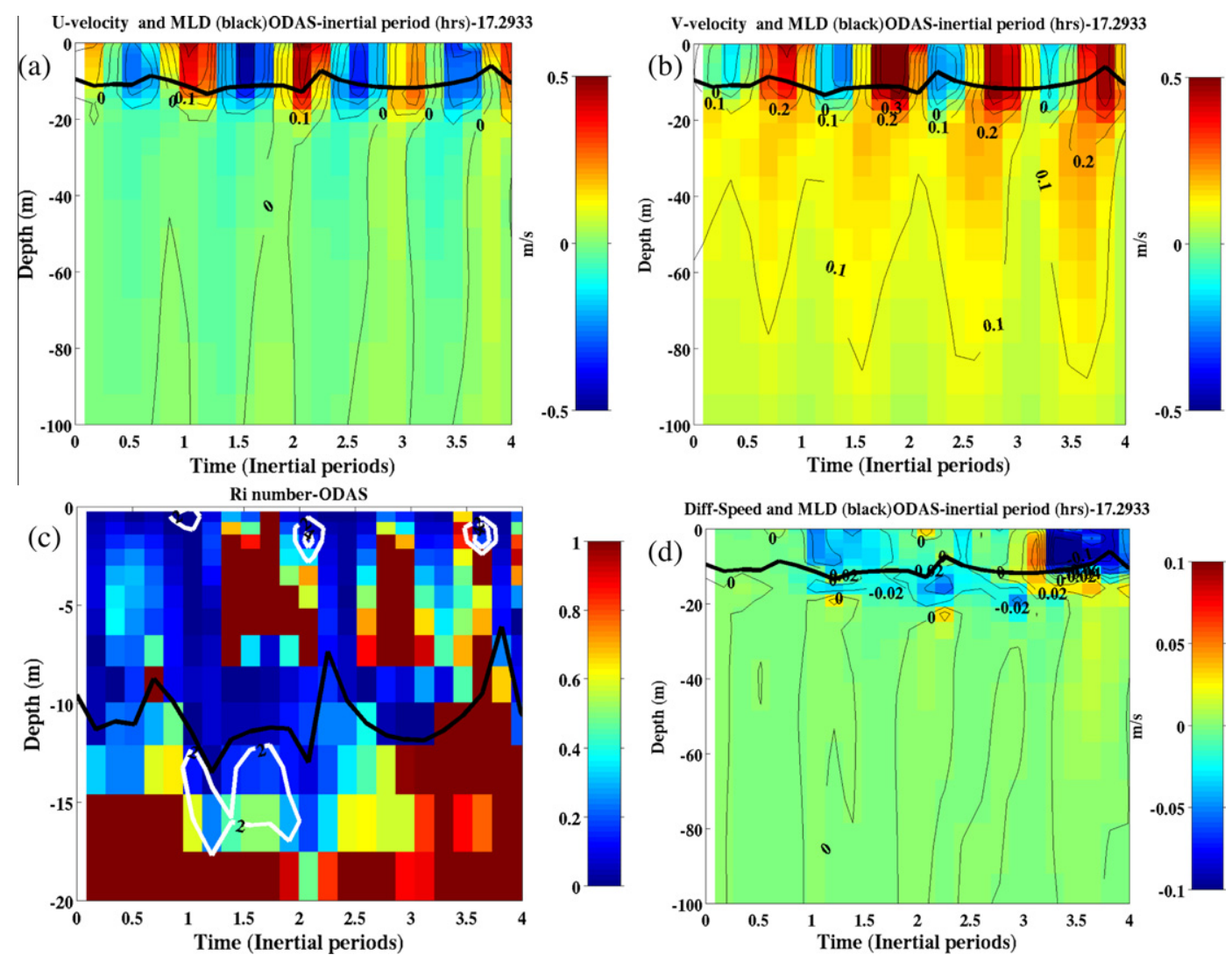

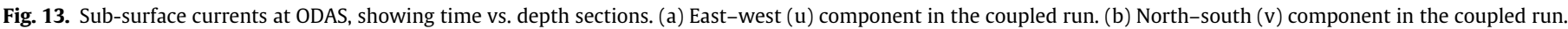

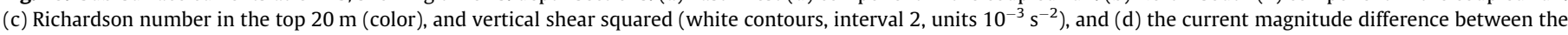

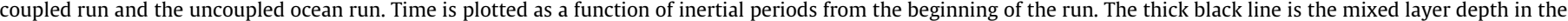

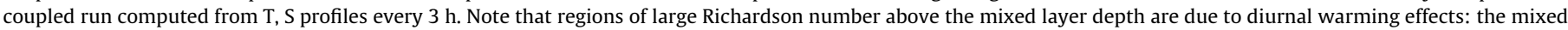
layer depth algorithm is set to start searching below $7 \mathrm{~m}$ and so ignores the stable diurnal warming layer.

change computed directly from the model output temperature fields, shown as a thin black line in Fig. 12. Differences between these two methods of computing temperature change are due to the fact that the budget terms are computed on the model sigma grid, whereas the full temperature fields were output after interpolation onto a set of fixed $z$ levels: this introduces differences when integrating to the mixed layer depth, most pronounced in shallow water (location SE, Fig. 12b).

At ODAS the temperature reduction of about $0.7^{\circ} \mathrm{C}$ after $69 \mathrm{~h}$ is mainly due to vertical mixing and horizontal advection (Fig. 12a). Here the time-averaged surface currents are from the south and west (Fig. 7a), advecting relatively cool water towards this location (as seen in Fig. 5, SST cools towards the center of the Ligurian Sea). In addition to this are oscillations due to inertial currents, discussed below. The mixed layer depth here stays between $10 \mathrm{~m}$ and $12 \mathrm{~m}$ throughout most of the run (Fig. 11a).

At location SE, in shallow water close to the east coast of Sardinia, horizontal advection and surface cooling are the main contributors to a temperature change of $0.6{ }^{\circ} \mathrm{C}$ after $69 \mathrm{~h}$ (Fig. 12b). The mean surface currents here are southward (Fig. 7a) which would advect cool temperatures east of the Strait towards SE. The contribution of vertical mixing here is a weak cooling whilst vertical advection applies warming ${ }^{4}$ (Fig. 12b): here the mixed layer deepens during the first $40 \mathrm{~h}$ of the run (Fig. 11c) due to the Ekman

${ }^{4}$ Note the effect of vertical advection within a completely uniform isothermal mixed layer should be zero: the small non-zero values result from the interpolation between model and regular vertical grid as discussed above, as well as the existence of any shallow diurnal warm layer. pumping effect (Fig. 10d). The vertically-averaged vertical mixing term is small here because of relatively weak winds at this location (Fig. 8e) and the large mixed layer depth and consequent difficulty to entrain thermocline water into the mixed layer.

At location NE, the largest cooling is seen, and it is mainly due to vertical mixing with a smaller contribution from surface fluxes. Temperature drops almost $3^{\circ} \mathrm{C}$ by $48 \mathrm{~h}$ before warming slightly, and is eventually $2{ }^{\circ} \mathrm{C}$ cooler than the initial value after $69 \mathrm{~h}$ (Fig. 12c). Vertical profiles of the vertical mixing term (not shown) confirm that there is significant entrainment from below the mixed layer base along with a coincident warming of the layer just below the mixed layer by up to $2^{\circ} \mathrm{C}$. Here the wind stress is strongest of the three locations (Fig. 10c): however, the mixed layer depth does not significantly deepen, (Fig. 11b), due to the Ekman pumping, a favorable situation for entrainment.

Finally, from Fig. 3b and d, it was seen that the western Gulf of Lions had weak cooling or even warmed, in contrast to the majority of the Ligurian Sea, despite reasonably strong winds. In this region there is some downwelling (Fig. 4b) as also discussed by Millot and Wald (1981). In this circumstance it is less likely to cool at the surface through vertical mixing, and a heat budget in this region (not shown) suggested that other processes such as horizontal advection and surface heat fluxes can dominate and in some circumstances cause warming.

\subsection{Inertial waves}

As a result of the strong Mistral wind bursts, inertial waves are generated, which can be seen in the zonal and meridional velocities 

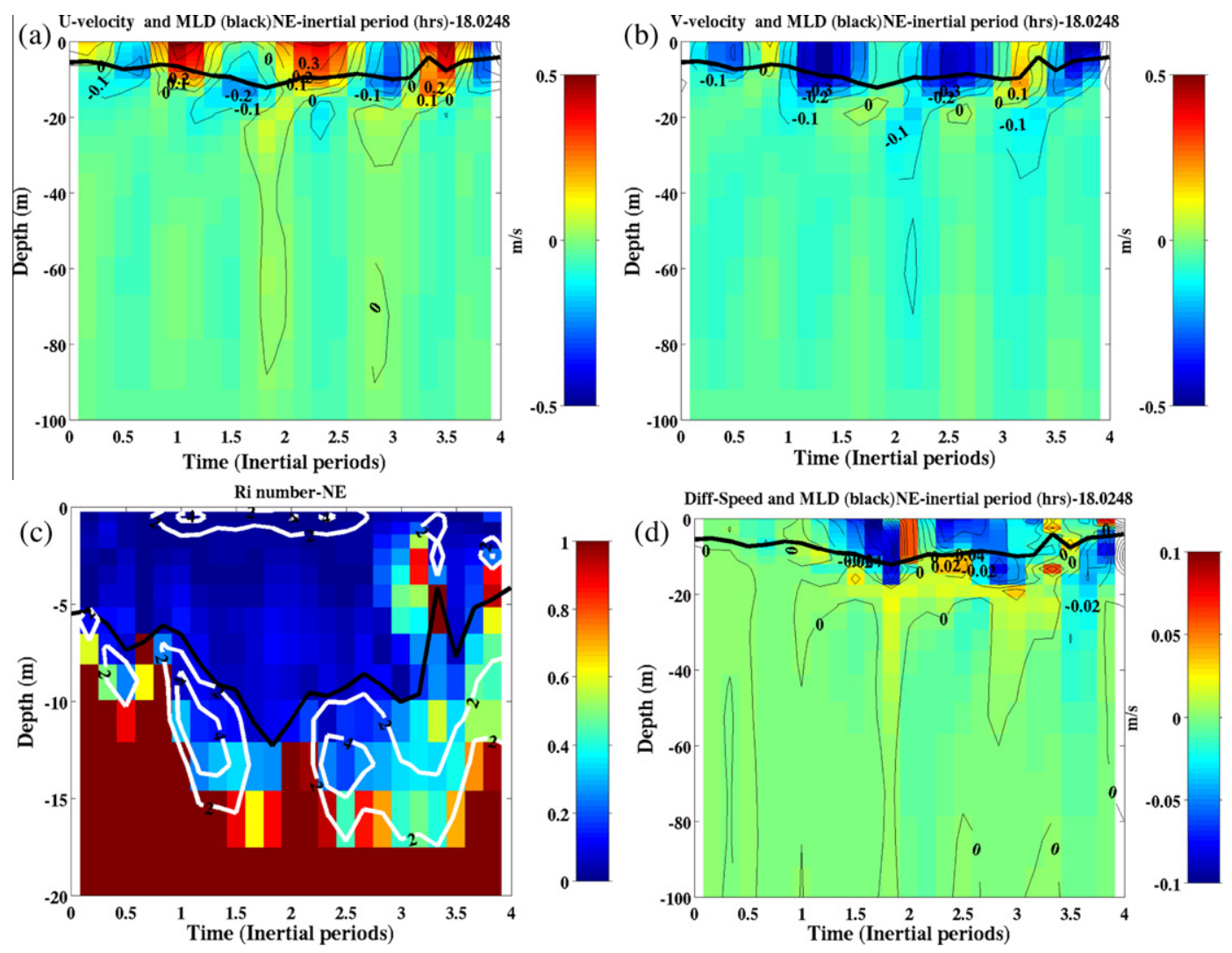

Fig. 14. As Fig. 13 but for the location north-east of Bonifacio.

at ODAS (Fig. 13a and b) and at NE (Fig. 14a and b). The velocity sections are plotted as a function of inertial period, $17.3 \mathrm{~h}$ at ODAS and $18.0 \mathrm{~h}$ at $\mathrm{NE}$. The modeled current oscillations have periods similar to the theoretical inertial periods, and rotate in a clockwise fashion with time.

At the base of the mixed layer there is very strong vertical shear as the currents drop from around $0.3 \mathrm{~m} \mathrm{~s}^{-1}$ to $0.5 \mathrm{~m} \mathrm{~s}^{-1}$ to near zero over a few meters depth. A well known necessary condition for shear instability is that the Richardson number $R i=N^{2} / S^{2}$ must drop below a critical value $R i_{c} \sim 0.25$ (Miles, 1961). Here $S$ is the vertical shear of the horizontal velocity so that $S^{2}=(\partial u / \partial z)^{2}+(\partial v / \partial z)^{2}$, and $N$ is the buoyancy frequency. At ODAS, and more prominently at NE, the shear-squared at and just below the base of the mixed layer can be larger than $2 * 10^{-3} \mathrm{~s}^{-2}$, enough to lead to patches of $R i<R i_{c}$ below the mixed layer depth (Figs. 13c and 14c). The results suggest that shear instability at the base of the mixed layer and the resulting entrainment of colder water masses below into the mixed layer (e.g. Nagai et al., 2005) is a dominant process for surface cooling at ODAS and NE. The high shear is due to the combination of the background currents and the inertial waves (L. Kantha, per. comm., 2012). Due to the shortness of the record it has proved difficult to separate these effects robustly using filters. However, visual inspection of Figs. 13a and b, and 14a and b suggests that inertial waves are contributing much of the shear, with the shear changing sign approximately every half inertial period.

Comparison of the subsurface velocity structure in the $C$ run vs. that in the UO run reveals slightly weaker inertial currents in the former (as seen from the reductions in current speed displayed in Figs. 13d and 14d). This could be a factor in the weaker SST cooling observed in the coupled run, particularly at NE, in addition to the effect of heat flux modification (Section 5).

Inertial waves have been frequently observed in the north-west Mediterranean Sea, for instance by Millot and Crépon (1981) in the
Gulf of Lions, Van Haren and Millot (2003) in the Ligurian Basin, and by Picco et al. (2010) at the ODAS mooring in previous years to this study. These papers note how important inertial and near-inertial waves are to the regional internal wave field, due to the relative absence of tidally generated internal waves. The results of our current work show that inertial waves are not just major components of the regional internal wave spectrum but are also important to regional air-sea interaction via shear-induced mixing and SST cooling.

\section{Discussion}

This study focuses on the ocean response to the Mistral and how that is affected by coupling, but has not addressed the feedback onto the synoptic system. The effect of coupling on synoptic atmospheric events has been addressed in some previous studies: the modification of surface stress and heat fluxes that arises either from rapidly changing SST (studied here; Perrie et al., 2004; Pullen et al., 2007; Chen et al., 2010; Sanford et al., 2011) or from rapidly changing surface wind-wave fields (Doyle, 1995; Janssen and Viterbo, 1996) will modify the synoptic system to some extent. As well as the classical damping effect of surface friction on synoptic storms via Ekman spindown (Holton, 2004), more recent studies have suggested that surface stress can influence interior potential vorticity and thus storm growth (Adamson et al., 2006), and surface heat fluxes also play an important role (e.g. Businger et al., 2005).

We limit our analysis here to showing the differences in selected atmospheric variables between the $C$ case and the uncoupled atmosphere (UA) case. First note that the difference in atmospheric Ekman pumping between the runs (Fig. 15a) suggests enhanced atmospheric downwelling (indicated in red and yellow) 

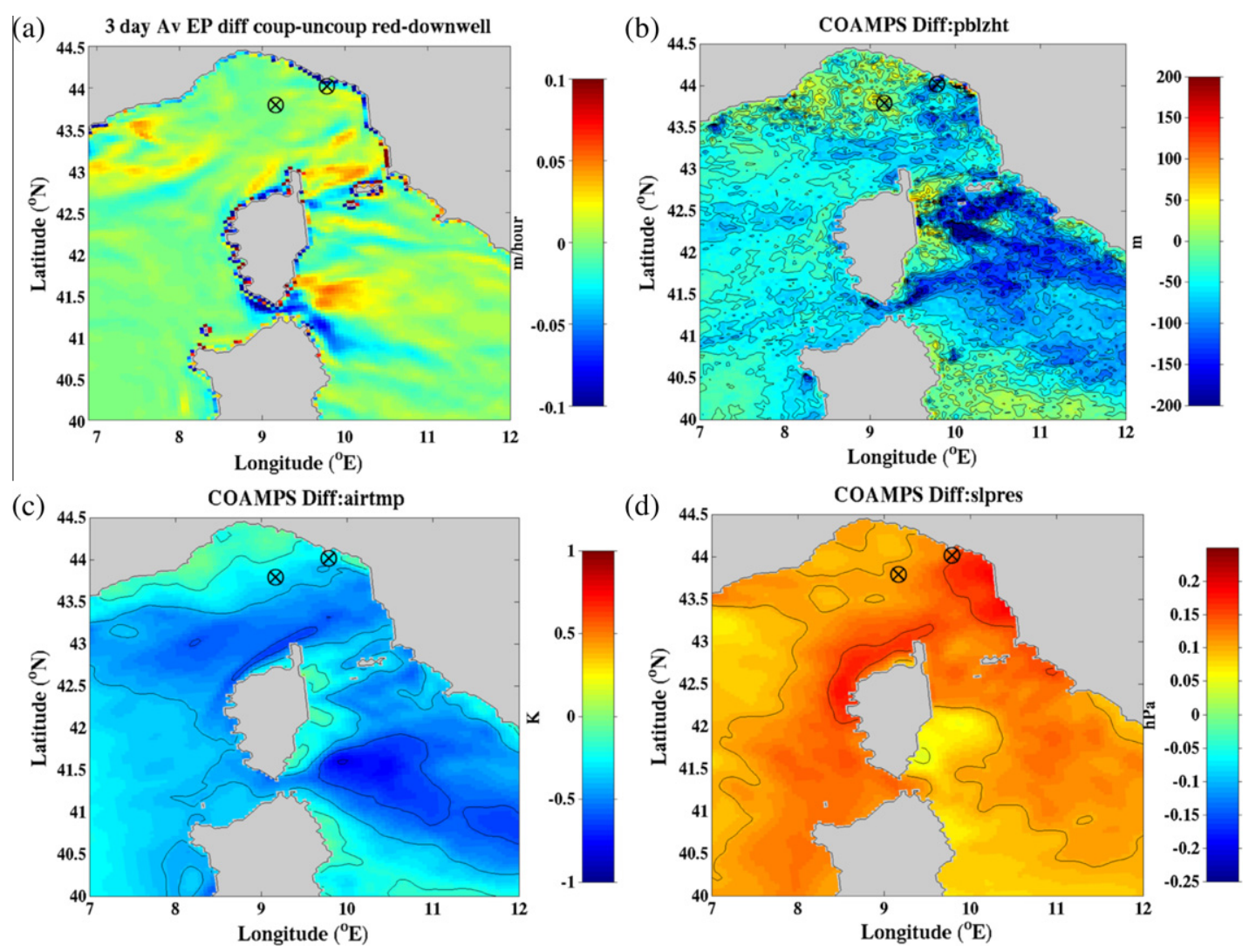

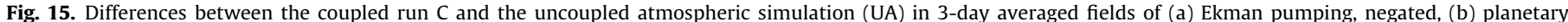

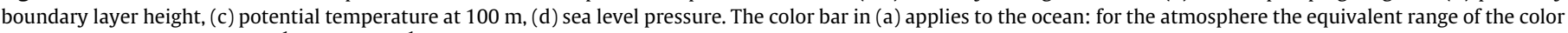
bar should be from $-100 \mathrm{~m} \mathrm{~h}^{-1}$ to $100 \mathrm{~m} \mathrm{~h}^{-1}$, positive downwards convention such that red areas denote more downwelling.

in the coupled run in many regions. In addition, the reduced heat fluxes into the atmosphere in the $C$ case (Fig. 9c) will reduce the amount of convection and also act to lower the planetary boundary layer (PBL) height. Correspondingly the time-averaged PBL height is reduced by up to $150 \mathrm{~m}$ (Fig. 15b), a significant proportion of the mean height (less than $500 \mathrm{~m}$ in this region and in this model). As a consequence of the reduction of sensible heat flux in the coupled run, air temperature at $100 \mathrm{~m}$ is reduced by up to $0.5{ }^{\circ} \mathrm{C}$ (Fig. 15c), whilst relative humidity is increased by up to $5 \%$ (not shown), presumably as a result of the air cooling. These changes again occur in strong wind regions in the central Ligurian Sea and particularly east and north of the Strait of Bonifacio.

Despite these reasonably large changes to boundary layer properties, effects of coupling above the boundary layer are weak, and the overall influence of coupling on the synoptic low pressure system, as illustrated in Fig. 15d, is a small increase of time-averaged sea level pressure (SLP) by less than $0.25 \mathrm{hPa}$. In other words, coupling reduces the strength of the synoptic low, but only by a small amount. This is despite the fact that the surface stress and friction, and Ekman spindown (compare Fig. 15a and Fig. 10d) are overall weaker in the coupled run compared to the uncoupled run. This suggests that other mechanisms than Ekman spindown may be at play, such as the effect of stress on potential vorticity, or the influence of heat fluxes. For example, in studies of the atmospheric boundary response to ocean fronts, reviewed by Small et al. (2008), typical SLP responses were $0.1 \mathrm{hPa}(-0.1 \mathrm{hPa})$ per ${ }^{\circ} \mathrm{C}$ of cooling (warming) by an ocean front. This is consistent with the 0.1$0.2 \mathrm{hPa}$ SLP response (Fig. 15d) to the $1-2{ }^{\circ} \mathrm{C}$ SST cooling shown in Fig. 8a. However, to address this issue in more detail would best require an ensemble of simulations, or a much longer simulation encompassing several events, not done for this study.

\section{Conclusions}

This study has analysed the role of air-sea interaction in the evolution of a Mistral wind event and the consequent ocean response. A 3-day case study was performed, for the summer, when the seasonal thermocline is strong. Observations were compared to coupled and uncoupled simulations performed using the high resolution, km scale, COAMPS-NCOM models. Both simulations start with the same initial conditions, but for the uncoupled run the SST used to calculate surface fluxes was kept fixed at the initial value. The main findings are as follows:

1. In regions where the wind forcing was strongest, the SST changed significantly over the course of the simulation period (by 2$3{ }^{\circ} \mathrm{C}$ over $72 \mathrm{~h}$ ). Much of the change occurred in the first $24 \mathrm{~h}$, when wind speeds up to $18 \mathrm{~m} \mathrm{~s}^{-1}$ and corresponding surface stresses of $0.4-0.6 \mathrm{Nm}^{-2}$ were observed. Although the broad spatial pattern of the model SST response matched the observations well, pointwise analysis of the SST evolution revealed differences, including an underestimation of the response at the mooring site ODAS, related to weak wind forcing in the model.

2. Interactive coupling of the ocean to the atmosphere model led to a significant reduction in surface stress (up to 20\%) and latent heat flux (up to 50\%) relative to that found in an uncoupled atmospheric model run using a SST fixed in time as surface boundary condition.

3. In turn, this led to a reduction of the magnitude of SST cooling (by up to $1{ }^{\circ} \mathrm{C}$, or about $25 \%$ to $33 \%$ ), in the interactive coupled run relative to an uncoupled ocean simulation. This was consistent with a simple estimation of the response of a $10 \mathrm{~m}$ thick ocean mixed layer to the surface heat flux changes induced by coupling. 
4. Large amplitude inertial waves, with velocities of $\sim 0.5 \mathrm{~m} \mathrm{~s}^{-1}$, and strong vertical shear, contributed significantly to the mixing process and surface cooling in the model simulations. Hence the mechanisms of SST response are similar to that found previously in tropical cyclones and extratropical low pressure systems (Chang and Anthes, 1978; Price, 1981; Large and Crawford, 1995; Dohan and Davis, 2011).

5. The summer Mistral briefly halts the restratification process in most regions of the Ligurian/Tyrrhenian Sea. The mixed layer is deepened and the surface is cooled. When active coupling is introduced, the surface cooling is less, and there is less destabilizion of the profile compared to the uncoupled run.

Although the SST response reported in this paper is much less than those found during some tropical cyclones (especially slowmoving hurricanes which can lead to SST cooling up to $6{ }^{\circ} \mathrm{C}$ (Bender and Ginis, 2000; Perrie et al., 2004; Chen et al., 2010)), it is comparable to that seen in the Northern Pacific during the passage of extratropical low pressure systems (Large et al., 1986; Large and Crawford, 1995; Dohan and Davis, 2011). Unlike tropical cyclones, Mistral events occur in basically the same location each time, and as up to ten Mistral events occur in a typical summer (see Introduction), the total SST cooling caused by these events in one season is significant.

To test these ideas further in the future, and to see the rectified effect over longer time periods, it would be useful to conduct numerical experiments over a whole season, or year, comparing a model with frequent coupling (e.g. $12 \mathrm{~min}$ ) against a weakly coupled model with feedback from the ocean only every 3 days (as done for this short test case). Validation data should be gathered in regions of reasonably strong winds where possible, such as in the central Ligurian Sea and east of the Strait of Bonifacio, instrumented in a similar way to ODAS in the LASIE07 experiment (Sempreviva et al., 2010; Small et al., 2011) to capture surface fluxes and near-surface quantities.

\section{Acknowledgements}

Three anonymous reviewers are thanked for their significant comments which improved the paper. Sue Chen (NRL) is thanked for her development of COAMPS code and willingness to answer questions. Travis Smith (NRL) helped test and set up the model experiments and provided helpful discussions. Roberto Bozzano (CNR ISSIA) allowed access to ODAS data as part of the LASIE07 experiment. Pierre-Marie Poulain (OGS) allowed access to drifter data and figures. We are grateful to Joerg Forster (Forschungsanstalt der Bundeswehr fur Wasserschall und Geophysik, Kiel, Germany) and colleagues for providing RV Planet data. Lakshmi Kantha provided helpful comments on the Richardson number and shear analysis. RJS, TC, and RA were supported by the High Performance Computing Modernization Program's Battlespace Environments Institute and NRL's 6.2 Core Program "Coupled OceanWave Modeling System" (Program Element PE 0602435N). SC acknowledges the support from the EU funded "FIELD_AC" Project, Grant Agreement 242284.

\section{References}

Aebischer, U., Schär, C., 1998. Low level potential vorticity and cyclogenesis in the lee of the Alps. J. Atmos. Sci. 55, 186-207.

Adamson, D.S., Belcher, S.E., Hoskins, B.J., Plant, R.S., 2006. Boundary-layer friction in mid-latitude cyclones. Quart. J. Roy. Met. Soc. 132, 101-124.

Allard, R.A., Campbell, T.J., Small, R.J., Smith, T.A., Jensen, T.G., Chen, S., Cummings, J.A., Doyle, J.D., Hong, X., Carroll, S.N., 2010. Validation Test Report for the Coupled Ocean Atmospheric Mesoscale Prediction System (COAMPS) Version 5. Naval Research Laboratory Report, NRL/MR/7322-10-9283. <http:// www7320.nrlssc.navy.mil/pubs/2010/allard2-2010.pdf>.
Artale, V., Astraldi, M., Buffoni, C., Gasparini, G.P., 1994. The seasonal variability of gyre-scale circulations in the northern Tyrrhenian Sea. J. Geophys. Res. 99, $14127-14137$

Artale, V. et al., 2010. An atmosphere-ocean regional climate model for the Mediterranean area: assessment of a present climate simulation. Clim. Dynam. 35, 721-740.

Barron, C.N., Kara, A.B., Martin, P.J., Rhodes, R.C., Smedstad, L.F., 2006. Formulation, implementation and examination of vertical coordinate choices in the Global Navy Coastal Ocean Model (NCOM). Ocean Modell. 11, 347-375.

Barth, A., Alvera-Azcarate, A., Rixen, M., Beckers, J.-M., 2005. Two-way nested model of mesoscale circulation in the Ligurian Sea. Prog. Oceanogr. 66, 171189.

Bender, M.A., Ginis, I., 2000. The operational GFDL coupled hurricane-ocean prediction system and a summary of its performance. Mon. Wea. Rev. 135, 3965-3989.

Bignami, F., Bohm, E., D’Acunzo, E., D’Archino, R., Salusti, E., 2008. On the dynamics of surface cold filaments in the Mediterranean Sea. J. Mar. Syst. 74, 429-442.

Blumberg, A.F., Mellor, G.L., 1987. A description of a three-dimensional coastal ocean circulation model. In: Three-Dimensional Coastal Ocean Models. In: Heaps, N. (Ed.), . Coastal Estuarine Ser, vol. 4. AGU, Washington D.C, pp. 1-16.

Businger, S., Graziano, T.M., Kaplan, M.L., Rozumalski, R.A., 2005. Cold-air cyclogenesis along the Gulf Stream front: investigation of diabatic impacts on cyclone development, frontal structure and track. Meteor. Atmos. Phys. 88, 6590.

Buzzi, A., Speranza, A., 1983. Cyclogenesis in the lee of the Alps. In: Lilly, E.D.K., GalChen, T. (Eds.), Mesoscale Meteorology - Theories, Observations and Models: Proceedings of the Advanced Study Institute, Bonas, Gers, France: Netherlands 13-31 July 1982. D. Reidel Publishing Company, pp. 55-142.

Carniel, S., Umgiesser, G., Kantha, L.H., Monti, S., Sclavo, M., 2002. Tracking the drift of a human body in the coastal ocean using Numerical Prediction Models of the oceanic, atmospheric and wave conditions. Sci. Justice 42 (3), 143-151.

Carniel, S., Kantha, L., Bergamasco, A., Prandke, H., Small, R.J., Sclavo, M., 2010. Layered structures in the upper Ligurian sea. Il Nuovo Cimento B 125 (12), 1567-1586. doi:10.1393/ncb/i2010-10945-8.

Chang, S.W., Anthes, R.A., 1978. Numerical simulations of the Ocean's nonlinear, baroclinic response to translating hurricanes. J. Phys. Oceanogr. 8, 468-480.

Chen, S., and co-authors, 2003. COAMPS Version 3 Model Description. NRL publication NRL/PU/7500-03-448 May 2003

Chen, S., Campbell, T.J., Jin, H., Gaberšek, S., Hodur, R.H., Martin, P., 2010. Effect of two-way air-sea coupling in high and low wind speed regimes. Mon. Wea. Rev. 138, 3579-3602.

Crépon, M., Boukthir, M., Barnier, B., Aikman III, F., 1989. Horizontal ocean circulation forced by deep water formation. Part I: an analytical study. J. Phys. Oceanogr. 19, 1781-1792.

Cummings, J.A., 2005. Operational multivariate ocean data assimilation. Q. J. R. Meteor. Soc. 131, 3583-3604.

Dohan, K., Davis, R.E., 2011. Mixing in the transition layer during two storm events. J. Phys. Oceanogr. 41, 42-66.

Doyle, J.D., 1995. Coupled ocean wave/atmosphere mesoscale model simulations of cyclogenesis. Tellus 47A, 766-778.

Drobinski, P., Bastin, S., Guenard, V., Caccia, J.-L., Dabas, A.M., Delville, P., Protat, A., Reitebuch, O., Werner, C., 2005. Summer mistral at the exit of the Rhone valley. Quart. J. Roy. Met. Soc. 131, 353-375.

Estournel, C., Durrieu de Madron, X., Marsaleix, P., Auclair, F., Julliand, C., Vehil, R. 2003. Observation and modeling of the winter coastal oceanic circulation in the Gulf of Lion under wind conditions influenced by the continental orography. J. Geophys. Res. 108. doi:10.1029/2001JC000825.

Flamant, C., 2003. Alpine lee cyclogenesis influence on air-sea heat exchanges and marine atmospheric boundary layer thermodynamics over the western Mediterranean during a Tramontane/Mistral event. J. Geophys. Res. 108. doi:10.1029/2001JC001040.

Herbaut, C., Martel, F., Crépon, M., 1997. A sensitivity study of the general circulation of the western Mediterranean Sea. Part II: the response to atmospheric forcing. J. Phys. Oceanogr. 27, 2126-2145

Hodur, R.M., 1997. The naval research laboratory's coupled ocean/atmosphere mesoscale prediction system (COAMPS). Mon. Wea. Rev. 135, 1414-1430.

Holton, J.R., 2004. An Introduction to Dynamical Meteorology. Section 5.4, fourth ed. Elsevier Academic Press, London, 535pp.

Janssen, P.A.E.M., Viterbo, P., 1996. Ocean waves and the atmospheric climate. J. Clim. 9, 1269-1287.

Jensen, T.G., Campbell, T., Allard, R., Small, R.J., Smith, T., 2011. Turbulent heat fluxes during an intense cold-air outbreak over the Kuroshio Extension Region: results from a high-resolution coupled atmosphere-ocean model. Ocean Dynam. 61, 657-674. doi:10.1007/s10236-011-0380-0.

Kara, A.B., Rochford, P.A., Hurlburt, H.E., 2000. An optimal definition for mixed layer depth. J. Geophys. Res. 105, 16803-16821.

Large, W.G., Crawford, G.B., 1995. Observations and simulations of upper ocean response to wind events during the Ocean Storms experiment. J. Phys. Oceanogr. 25, 2831-2852.

Large, W.G., McWilliams, J.C., Niiler, P.P., 1986. Upper ocean thermal response to strong autumnal forcing of the Northeast Pacific. J. Phys. Oceanogr. 16, 15241550.

Lebaupin-Brossier, C.L., Drobinski, P., 2009. Numerical high resolution air-sea coupling over the Gulf of Lions during two Tramontane/Mistral events. J. Geophys. Res. 114, D10110. doi:10.1029/2008JD011601. 
Liu, W.T., Katsaros, K.B., Businger, J.A., 1979. Bulk parameterization of air-sea exchanges of heat and water vapor including the molecular constraints at the interface. J. Atmos. Sci. 36, 1722-1735.

Malanotte-Rizoli, P., Robinson, A.R., 1994. Ocean Processes in Climate Dynamics: Global and Mediterranean Examples. Proceedings of the NATO Advanced Study Institute. Kluwer Academic Publishers, Dordrecht, 437pp.

Martin, P.J., Book, J.W., Doyle, J.D., 2006. Simulation of the northern Adriatic circulation during winter 2003. J. Geophys. Res.. doi:10.1029/2006JC003511.

Martin, P.J., 2000. A Description of the Navy Coastal Ocean Model Version 1.0, NRL Rep. NRL/FR/7322-00-9962, 42pp. Nav. Res. Lab., Stennis Space Center, Miss.

Marullo, S., Buongiorno Nardelli, B., Guarracino, M., Santoleri, R., 2007. Observing the Mediterranean from space: 21 years of Pathfinder-AVHRR sea surface temperatures (1985 to 2005): re-analysis and validation. Ocean Sci. 3, 299-310.

Millot, C., 1979. Wind induced upwellings in the Gulf of Lions. Oceanol. Acta 2, 262274.

Millot, C., Crépon, M., 1981. Inertial oscillations on the continental shelf of the Gulf of Lions - observations and theory. J. Phys. Oceanogr. 11, 639-657.

Millot, C., Wald, L., 1980. The effect of Mistral wind on the Ligurian current near Provence. Oceanol. Acta 3, 399-402.

Millot, C., Wald, L., 1981. Upwelling in the Gulf of Lions. In: Coastal Upwelling, American Geophysical Union Monograph, pp. 160-166.

Miles, J.W., 1961. On the stability of heterogeneous shear flows. J. Fluid Mech. 10, 496-508.

Nagai, T., Yamazaki, H., Nagashima, H., Kantha, L.H., 2005. Field and numerical studies of entrainment laws for surface mixed layer. Deep-Sea Res. 52, 11091132.

Perilli, A., Rupolo, V., Salusti, E., 1995. Satellite investigations of a cyclonic vortex in the central Tyrrhenian Sea (western Mediterranean Sea). J. Geophys. Res. 100, 2487-2499.

Perrie, W., Ren, X., Zhang, W., Long, Z., 2004. Simulation of extratropical Hurricane Gustav using a coupled atmosphere-ocean-sea spray model. Geophys. Res. Letts. 31, L03110. doi:10.1029/2003GL018571.

Pettre, P., 1982. On the problem of violent valley winds. J. Atmos. Sci. 39, 542-554.

Picco, P., Capelletti, A., Sparnocchia, S., Schiano, M.E., Pensieri, S., Bozzano, R., 2010. Upper layer current variability in the Central Ligurian Sea. Ocean Sci. Disc. 7, 445-475.

Pinardi, N., Masetti, E., 2000. Variability of the large scale general circulation of the Mediterranean Sea from observations and modeling: a review. Paleogeogr. Paleoclimatol. Paleoecol. 158, 153-173.

Pinardi, N. et al., 2003. The Mediterranean ocean forecasting system: first phase of implementation (1998-2001). Ann. Geophys. 21, 3-20.

Poulain and co-authors, submitted for publication. Aspects of the Surface Circulation in the Liguro-Provencal Basin and Gulf of Lion as Observed by
Satellite-tracked Drifters (2007-2009), Bollettino di Geofisica Teorica e Applicata.

Price, J.F., 1981. Upper ocean response to a hurricane. J. Phys. Oceanogr. 11, 153175.

Pullen, J., Doyle, J.D., Haack, T., Dorman, C., Signell, R.P., Lee, C.M., 2007. Bora event variability and the role of air-sea feedback. J. Geophys. Res. 112. doi:10.1029/ 2006JC003276.

Salusti, E., 1998. Satellite images of upwellings and cold filament dynamics as transient effects of violent air-sea interactions downstream from the island of Sardinia. J. Geophys. Res. 103, 3013-3031.

Sanford, T., Price, J.F., Girton, J.B., 2011. Upper-ocean response to hurricane Frances (2004) observed by profiling EM-APEX floats. J. Phys. Oceanogr. 41, 1041-1056.

Schiano, M.E., Santoleri, R., Bignami, F., Leonardi, R.M., Marullo, S., Bohm, E., 1993. Air-sea interaction measurements in the West Mediterranean Sea during the Tyrrhenian Eddy Multi-Platform Observations Experiment. J. Geophys. Res. 98, 2461-2474.

Schott, F., Visbeck, M., Send, U., Fischer, J., Stramma, L., Desaubies, Y., 1996. Observations of deep convection in the Gulf of Lions, northern Mediterranean during the winter of 1991-1992. J. Phys. Oceanogr. 26, 505-524.

Schroeder, K., Haza, A.C., Griffa, A., Ozgokmen, T.M., Poulain, P.M., Gerin, R., Peggion, G., Rixen, M., 2011. Relative dispersion in the Liguro-Provencal basin: from submesoscale to mesoscale. Deep-Sea Res. I 58, 209-228.

Sempreviva, A.M., Schiano, M.E., Pensieri, S., Bozzano, R., Borghini, M., Grasso, F., Semedo, A., Soerensen, L.L., Teixeira, J., Transerici, C., Tome, R., 2010. Observed development of the vertical structure of the marine boundary layer during the LASIE experiment in the Ligurian Sea. Ann. Geophys. 28, 17-25.

Small, R.J., Campbell, T., Teixeira, J., Carniel, S., Smith, T.A., Dykes, J., Chen, S., Allard, R., 2011. Air-sea interaction in the Ligurian Sea: assessment of a coupled oceanatmosphere model using in situ data from LASIE07. Mon. Wea. Rev. 139 (6), 1785-1808. doi:10.1175/2010MWR3431.1.

Small, R.J., DeSzoeke, S.P., Xie, S.-P., O’Neill, L., Seo, H., Song, Q., Cornillon, P., Spall, M., Minobe, S., 2008. Air-sea interaction over ocean fronts and eddies. Dyn. Atmos. Ocean. 45, 274-319, org/10.1016/j.dynatmoce.2008.01.001.

Somot, S., Sevault, F., Deque, M., Crepon, M., 2008. 21st Century climate change scenario for the Mediterranean using a coupled atmosphere-ocean regional climate model. Global Planet. Change 63, 112-126.

Teixeira, J., 2007. Ligurian Sea Air-Sea Interaction Experiment (LASIE) Trial Plan. NATO Undersea Research Centre, La Spezia, Italy, 30 pp.

Van Haren, H., Millot, C., 2003. Seasonality of internal gravity waves kinetic energy spectra in the Ligurian Basin. Oceanol. Acta 26, 635-644.

Wentz, F.J., Smith, D.K., 1999. A model function for the ocean-normalised radar cross-section at $14 \mathrm{GHz}$ derived from NSCAT observations. J. Geophys. Res. 104, 11499-11514. 